\title{
Article \\ The Influence of the Material Structure on the Mechanical Properties of Geopolymer Composites Reinforced with Short Fibers Obtained with Additive Technologies
}

\author{
Kinga Korniejenko ${ }^{1, *(\mathbb{D})}$, Pavel Kejzlar ${ }^{2} \mathbb{( 1 )}$ and Petr Louda ${ }^{2}(\mathbb{D}$ \\ 1 Faculty of Material Engineering and Physics, Cracow University of Technology, 37 Jana Pawła II Street, \\ 31-864 Cracow, Poland \\ 2 Department of Material Science, Faculty of Mechanical Engineering, Technical University of Liberec, \\ 2 Studenstká Street, 46117 Liberec, Czech Republic; pavel.kejzlar@tul.cz (P.K.); petr.louda@tul.cz (P.L.) \\ * Correspondence: kkorniejenko@pk.edu.pl
}

check for updates

Citation: Korniejenko, K.; Kejzlar, P.; Louda, P. The Influence of the Material Structure on the Mechanical Properties of Geopolymer Composites Reinforced with Short Fibers Obtained with Additive Technologies. Int. J. Mol. Sci. 2022, 23, 2023. https://doi.org/10.3390/ ijms23042023

Academic Editor: Daniel Arcos

Received: 29 January 2022

Accepted: 10 February 2022

Published: 11 February 2022

Publisher's Note: MDPI stays neutral with regard to jurisdictional claims in published maps and institutional affiliations.

Copyright: (c) 2022 by the authors. Licensee MDPI, Basel, Switzerland. This article is an open access article distributed under the terms and conditions of the Creative Commons Attribution (CC BY) license (https:/ / creativecommons.org/licenses/by/ $4.0 /)$.

\begin{abstract}
Additive manufacturing technologies have a lot of potential advantages for construction application, including increasing geometrical construction flexibility, reducing labor costs, and improving efficiency and safety, and they are in line with the sustainable development policy. However, the full exploitation of additive manufacturing technology for ceramic materials is currently limited. A promising solution in these ranges seems to be geopolymers reinforced by short fibers, but their application requires a better understanding of the behavior of this group of materials. The main objective of the article is to investigate the influence of the microstructure of the material on the mechanical properties of the two types of geopolymer composites (flax and carbon-reinforced) and to compare two methods of production of geopolymer composites (casting and 3D printing). As raw material for the matrix, fly ash from the Skawina coal power plant (located at: Skawina, Lesser Poland, Poland) was used. The provided research includes mechanical properties, microstructure investigations with the use of scanning electron microscope (SEM), confocal microscopy, and atomic force microscope (AFM), chemical and mineralogical (XRD-X-ray diffraction, and XRF-X-ray fluorescence), analysis of bonding in the materials (FT-IR), and nuclear magnetic resonance spectroscopy analysis (NMR). The best mechanical properties were reached for the sample made by simulating 3D printing process for the composite reinforced by flax fibers (48.7 MPa for the compressive strength and 9.4 MPa for flexural strength). The FT-IR, XRF and XRD results show similar composition of all investigated materials. NMR confirms the presence of $\mathrm{SiO}_{4}$ and $\mathrm{AlO}_{4}$ tetrahedrons in a three-dimensional structure that is crucial for geopolymer structure. The microscopy observations show a better coherence of the geopolymer made in additive technology to the reinforcement and equal fiber distribution for all investigated materials. The results show the samples made by the additive technology had comparable, or better, properties with those made by a traditional casting method.
\end{abstract}

Keywords: geopolymer composite; flax fiber; carbon fiber; 3D printable geopolymer

\section{Introduction}

Geopolymers are sometimes called inorganic aluminosilicate polymers and are generally obtained in the reaction of ortosilican polycondensation [1,2]. Common raw materials for the geopolymerization process are metakaolin, calcined clays, industrial waste and by-products (e.g., ash, slag, glass waste, red mud, mine tailings, for example: copper, vanadium), gauges, etc. or other natural and artificial silicoaluminates (e.g., zeolite, pure $\mathrm{Al}_{2} \mathrm{O}_{3}-2 \mathrm{SiO}_{2}$ powder, as well as minerals containing magnesium [2-4]. Nowadays, geopolymers are not only being researched, but they have also has been used in real-life civil engineering applications. The most spectacular examples are the Global Change Institute (GCI) building at the University of Queensland in Australia and the Wellcamp airport in Brisbane, Australia [5,6]. However, these materials are also used in the production of 
construction materials such as the fire-resistant wood panels, sandwich panels and other building elements, heat shields for space shuttles, as well as fire barriers in the construction industry, protective coating in emergency repair runways, material for the support to the stabilization of toxic waste, including radioactive substances and other applications [7-10].

Today, interest in the practical application of geopolymers is increasing due to a growing public awareness of the need to protect the environment. Geopolymer composites appear to be the most promising environmentally friendly alternative to traditional cementitious materials, including Portland cement [1,11]. Production of geopolymers results in a much lower carbon footprint than traditional construction materials [2,12]. It allows one to reduce the emission of $\mathrm{CO}_{2}$ and other substances harmful to the environment and at the same time save natural resources by using waste [4,13]. Additionally, the geopolymerization process allows different wastes streams to be used as a raw materials $[4,14]$. The surplus environmental benefits could be achieved by using the appropriate production technology, such as additive manufacturing [15-17].

Now, the technology of additive manufacturing develops rapidly in the construction industry $[17,18]$. It provides new horizons in this sector, especially in terms of geometric flexibility, reduction in labor costs, improvement of efficiency and safety, construction in harsh environments, and sustainability $[19,20]$. The important element is also the improvement of efficiency and safety, as well as the reduction in costs, especially related to manpower [17]. The additive technology also reduces waste, including waste related to formwork construction $[15,17]$. Not only is a smaller amount of material used for molding and casting operations, but also the technology offers the possibility of optimizing the construction, and it finally reduces the amount of material used during the process. An extra benefit is a reduction in the cost of transportation through the possibility of the production "in place" and using local waste materials [15,21]. However, the full exploitation of additive technology for effective application still requires optimization, especially with respect to improving methods of designing new materials [17,22].

The ceramic materials dedicated to additive technology must have a good combination of all essential material properties dedicated to traditional technology such as: proper durability, ductility, vapor imperviousness, high tensile and compressive strength, low coefficient of thermal expansion, resistance to UV light and others [18,20], as well as properties connected with additive technologies, especially short time of curing, proper viscosity and time of bounding $[18,23]$. The properties most often cited in the literature are as follows:

(1) Pumpability - the reliability of the material that is moved through the delivery system [18];

(2) Printability or extrudability-depositing material through a deposition device or defined as state to pass or be pumped through a small nozzle [18,20];

(3) Buildability - resistance of deposited wet material to deformation under loads or defined as holding the shape under the weight of subsequently printed layers $[18,20]$;

(4) Interlayer bonding and segregation prevention [20];

(5) Open time-period while the aforementioned properties remain consistently within acceptable tolerances $[18,20]$ and sufficient viscosity to retain its shape after the printing process $[19,24]$;

(6) Thixotropic properties (high yield strength and low viscosity behavior) [19];

(7) Proper post-processing procedures [25,26].

Another significant problem is reinforcing additive technology; steel bars, well known from traditional concrete technology, must be replaced by short or long ones. In the case of ceramic materials such as geopolymers, reinforcement is highly required, due to their limited brittle behavior [2,20]. However, it also requires modern technological solutions, including the proper design of composition and modifications in the manufacturing process [27-29]. Until now, only a few studies have been conducted in the area of fiber-reinforced composites made in additive technologies [2]. They were focused on:

(1) Long steel fibers [30-32], 
(2) Short steel fibers [33],

(3) Short glass fibers [34],

(4) Short carbon and flax fibers [16],

(5) Different kinds of plastic fibers, including polypropylene fibers (PP), polyvinyl fibers (PVA) and polybenzoxazole fibers (PBO) [33,35-37].

The most important works on this topic are summarized in Table 1.

Table 1. Types of fibers used in geopolymer composites manufactured by 3D printing.

\begin{tabular}{|c|c|c|c|}
\hline Fiber & Matrix & Fiber Influence & Source \\
\hline $\begin{array}{c}\text { Steel micro-cable } \\
\text { stainless steel grade SUS304; } \\
\text { diameter: } 1.2 \text { mm; amount: } 0.8 \% \\
\text { by vol. }\end{array}$ & $\begin{array}{c}\text { Fly ash class } F(0.64) \text {, silica fume } \\
(0.11) \text {, slag }(0.25) \text {, fine silica sand } \\
(1.2) \text {, sodium metasilicate } \\
\text { pentahydrate powder }(0.125) \text {, tap } \\
\text { water }(0.348), \text { PP fibers }(0.0056) \\
\text { and VMA, hydroethylcellulose. }\end{array}$ & $\begin{array}{l}\text { The 3D printed micro-cable } \\
\text { reinforced geopolymer } \\
\text { composite reaches the highest } \\
\text { flexural strength (up to eight } \\
\text { times) and deflection resistance } \\
\text { (up to seventy times) when the } \\
\text { filaments are deposited in an } \\
\text { incline-crossed printing } \\
\text { configuration compared to a } \\
\text { nonreinforced one. } \\
\text { The failure mode of the } \\
\text { reinforced structures changed } \\
\text { from brittle to ductile and the } \\
\text { microcable reinforcement } \\
\text { altered the patterns of evolution } \\
\text { of the strain. } \\
\text { The reinforcement increases } \\
\text { resistance to deformation and } \\
\text { damage. } \\
\text { The test results demonstrated } \\
\text { that the micro-cables are } \\
\text { conductive. } \\
\text { Improved the load capacity of } \\
\text { spiderweb-like structures by } \\
\text { 132\%. } \\
\text { The bond between the } \\
\text { geopolymer and cable } \\
\text { reinforcement was proven to } \\
\text { be effective. }\end{array}$ & [30] \\
\hline $\begin{array}{l}\text { Hooked-end steel fibers; } \\
40 \mathrm{~mm} \text { length; diameter } \\
0.615 \mathrm{~mm} ; 1 \mathrm{wt} \% \\
\text { Polypropylene fiber; length: } \\
50 \mathrm{~mm} ; 0.5 \mathrm{wt} \%\end{array}$ & $\begin{array}{c}\text { F fly ash and sand; } \\
\text { sodium silicate and sodium } \\
\text { hydroxide solution with a } \\
\text { concentration of } 8.0 \mathrm{M} \text { were } \\
\text { utilized as activators }\end{array}$ & $\begin{array}{l}\text { Inclusion fibers had negative } \\
\text { effects on the bond strength } \\
\text { between layers. }\end{array}$ & [33] \\
\hline
\end{tabular}


Table 1. Cont.

$\begin{array}{lll}\text { Fiber } & \text { Matrix } & \text { Fiber Influence }\end{array}$

- $\quad$ Stiffness of the cable is an important factor-nylon, carbon fiber, aramid, and polyethylene cables with stiffness less than that of steel cables are found to knot and are not suitable for embedding in printing filament.

- $\quad$ Steel microcable (diameter: $1.2 \mathrm{~mm}$ )

- $\quad$ Nylon microcable $(1.3 \mathrm{~mm})$

- $\quad$ Carbon microcable $(1.4 \mathrm{~mm})$

- Aramid microcable $(0.8 \times 1.2 \mathrm{~mm})$

- Polyethylene microcable $(1.2 \mathrm{~mm})$
Class F low-calcium fly ash, ground granulated blast furnace slag, silica fume, sand with a maximum particle size of $1 \mathrm{~mm}$; Penta sodium metasilicate powder
- The tensile behavior depends on the cable reinforcement configurations.

- Polymer-based cables are better at increasing corrosion resistance than steel cables.

- $\quad$ The multi-cables introducing system is recommended for real construction practices.
- $\quad$ Polyvinyl alcohol (PVA) fibers; length: $8 \mathrm{~mm}$; amount $0.5 \mathrm{wt} \%$

- $\quad$ Stainless steel cable-SUS304; varying diameter: $1,1.5$ and $2 \mathrm{~mm}$.
$80 \%$ class F grade fly ash (FA) $15 \%$ ground granulated blast furnace slag and 5\% micro silica, fine river sand; potassium silicate
- The steel cable could improve the flexural strength of 3D printed material by $290 \%$.
- $\quad$ Fibers maintain the mechanical performance and durability of the printed element.

\section{[39]}

furnace slag; anhydrous sodium metasilicate (solid activator)

95\% metakaolin and 5\% silica fume;

PVA fibers; length: $3 \mathrm{~mm}$, amount: $0.5 \mathrm{wt} \%$ sodium silicate and $10 \mathrm{M}$ sodium hydroxide solutions
- $\quad$ Reduction in shrinkage in 3D printed, multifunctional geopolymer sensor-repair for concrete structures was presented.

- Increasing compressive strength, modulus of rupture, and deflection capacity.

Class F fly ash and granulated ground blast furnace slag; anhydrous sodium metasilicate powder with $\mathrm{SiO}_{2} / \mathrm{Na}_{2} \mathrm{O}$ mass ratio of 0.9
- The orientation of the fibers in the 3D-printed samples was found to be mainly parallel to the printing direction.

- The inclusion of short polymeric fibers results in higher porosity due to the entrapment of air in the mixture. 
Table 1. Cont.

\begin{tabular}{|c|c|c|c|}
\hline Fiber & Matrix & Fiber Influence & Source \\
\hline $\begin{array}{ll}\text { - } & \text { PVA } \\
\text { - } & \text { Polypropylene (PP) } \\
\text { Polyphenylene } \\
\text { benzobisoxazole (PBO) } \\
\text { All } 6 \text { mm length }\end{array}$ & $\begin{array}{c}\text { Class F fly ash, silica sands; } \\
\text { sodium-based activator } \\
\text { composed of } 8.0 \mathrm{M} \mathrm{NaOH} \text { and } \mathrm{N} \\
\text { Grade } \mathrm{Na}_{2} \mathrm{SiO}_{3} \text { solutions }\end{array}$ & $\begin{array}{l}\text { The flexural strength of the 3D } \\
\text { printed fiber-reinforced } \\
\text { geopolymer mixtures was } \\
\text { substantially higher for all } 3 \\
\text { types of fibers than that of the } \\
\text { 3D printed geopolymer } \\
\text { without fiber. }\end{array}$ & [35] \\
\hline
\end{tabular}

- $\quad$ Shape relations ability improved with fiber content.

- Fibers increase the compressive strength of the material only in the perpendicular direction

PP fibers; length: $6 \mathrm{~mm}$, four different fiber contents were chosen: $0.25,0.50,0.75$, and $1.00 \%$ by vol.

Fly ash, micron-scale silica sand alkaline solution composed sodium silicate and sodium, and sodium carboxymethyl cellulose (CMC) powder were used (parallel alignment of the fibers with the direction of the extrusion).

- $\quad$ Fiber increases the ductility, deflection capacity, and fracture energy.

- Increasing the volume of the fiber reduced the strength of the interlayer bond to some extent.

- The addition of wollastonite or glass fibers increases the viscosity and decreases the workability (castability) of the material.

callovo-oxfordian argillites, kaolin, sand; potassium silicate
- $\quad$ AR glass fibers $(6 \mathrm{~mm})$

- Wollastonite $(5-170 \mu \mathrm{m})$
Fly ash (class F), slag, micro silica, fine (river) sand; liquid potassium silicate; hydroxypropyl methylcellulose
- The fibers are oriented parallel to the printing path during the process.
Short glass fiber; lengths: 3, 6 and $8 \mathrm{~mm}$; amount: $0.25 \%-1 \%$ by vol.
- The addition of fiber barely improves compressive strength and significantly flexural and tensile strength.

\section{[34]}

- The inclusion of the fibers slightly enhanced compressive strength, and significantly enhanced flexural strength.

Class F fly ash, sand; aqueous solution of sodium hydroxide with $10 \mathrm{M}$, and an aqueous solution of sodium silicate, in a ratio of $1: 2.5$
Green tow flax fibers; length 30-50 mm; amount $1 \mathrm{wt} \%$.
- $\quad$ The performance of samples containing flax fibers was better than that of samples containing carbon fibers.
- $\quad$ The results for compressive and flexural strength are better for plain samples than ones with fibers, regardless of the technology of samples' manufacturing (3D printing and casting).
Class F fly ash, sand; aqueous solution of sodium hydroxide and sodium silicate
The provided analysis of the literature shows that reinforcement by short and long fibers is an effective way of reinforcing geopolymers dedicated to additive manufacturing 
technology, and it also provides a positive influence on flexural strength $[17,43]$. The most important benefits associated with using fibers as a reinforcement are as follows:

(1) Increasing flexural strength-for samples with fiber addition, it could be even $600 \%$ higher than for plain sample [30].

(2) Improving interlayer bonding, including influence of time intervals between layersreducing time gaps between additive layers and introducing fibers impact on the bond strength between subsequent layers [35].

(3) Laminating the cracking propagation and reducing brittle behavior of the geopolymers [16].

(4) Reducing shrinkage [40].

The main objective of the article is to investigate the influence of material microstructure on the mechanical properties of the two types of geopolymer composites (flax and carbon-reinforced) and to compare two methods of production for geopolymer composites (casting and 3D printing). These two types of fibers were selected to compare synthetic and natural ones. Carbon fiber was selected because it has the best mechanical properties and was previously applied in the geopolymer matrix [16,32]. This fiber has properties better than those of popularly used glass fibers and is resistant to alkali environment in geopolymer matrix. The main limitation in the wider application of this fiber is the price, which is much higher than in the case of glass or polymer fibers. The flax fiber was selected as an alternative to synthetic fibers. In central Europe (Poland and the Czech Republic), this fiber is one of the two plants of naturally growing fibers (flax and hemp). It is also waste product from the connected plant production. The selection of flax fibers was based on previous research in which these two natural fibers were compared.

2. Results

\subsection{Mechanical Properties-Compressive and Flexural Strength}

The samples were investigated with regard to their mechanical properties after 28 days $[16,44]$. A summary of these results is presented in Figure 1 [44].

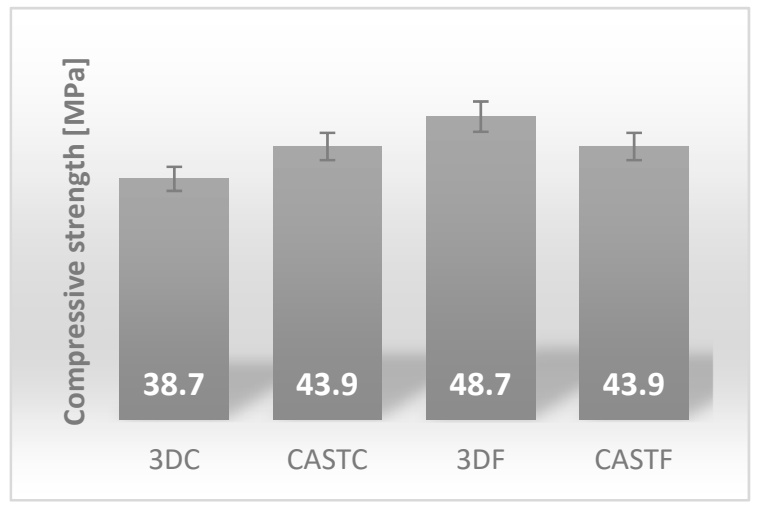

(a)

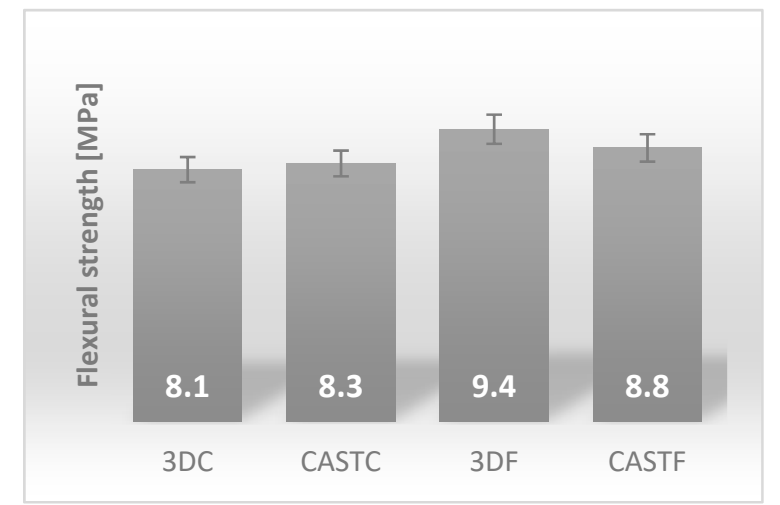

(b)

Figure 1. Mechanical properties: (a) compressive strength; (b) flexural strength.

The best value of the compressive strength was reached for the sample made by simulating a 3D printing process for the composite reinforced by flax fibers. It was about $48.7 \mathrm{MPa}$. Both of the casted samples were approximately $43.9 \mathrm{MPa}$. Geopolymer composites with the addition of $1 \%$ by weight of carbon fibers made by simulating the $3 \mathrm{D}$ printing process had the lowest compressive strength value, which was approximately $38.7 \mathrm{MPa}$ (Figure 1).

In the case of flexural strength, the values of the composite with flax fibers were significantly better than those of the reinforced carbon fibers. The best value of the flexural strength was reached again for the sample made by simulating the 3D printing process for the composite reinforced with flax fibers. It was about 9.4 MPa. The casted sample 
reinforced with flax fiber achieved a value of $8.8 \mathrm{MPa}$. The results for the samples reinforced by carbon fibers were $8.3 \mathrm{MPa}$ for the casted sample and $8.1 \mathrm{MPa}$ for the sample made by simulating the 3D printing process, respectively (Figure 1). The unexpected finding in this research was the very high values of compressive and flexural strength of the composite with flax fibers in comparison to the composite with carbon fibers [16,44]. Taking into consideration this fiber's properties, the results should be different, because the carbon fibers have better mechanical properties than flax fibers.

\subsection{Analysis of Bonding in the Material with the Use of Fourier-Transform Infrared Spectroscopy (FT-IR)}

Figure 2 shows the FT-IR spectra for the geopolymer composites. The patterns for all compositions are quite similar. There is a lack of significant differences between particular composites and a lack of differences between materials manufactured using different methods.

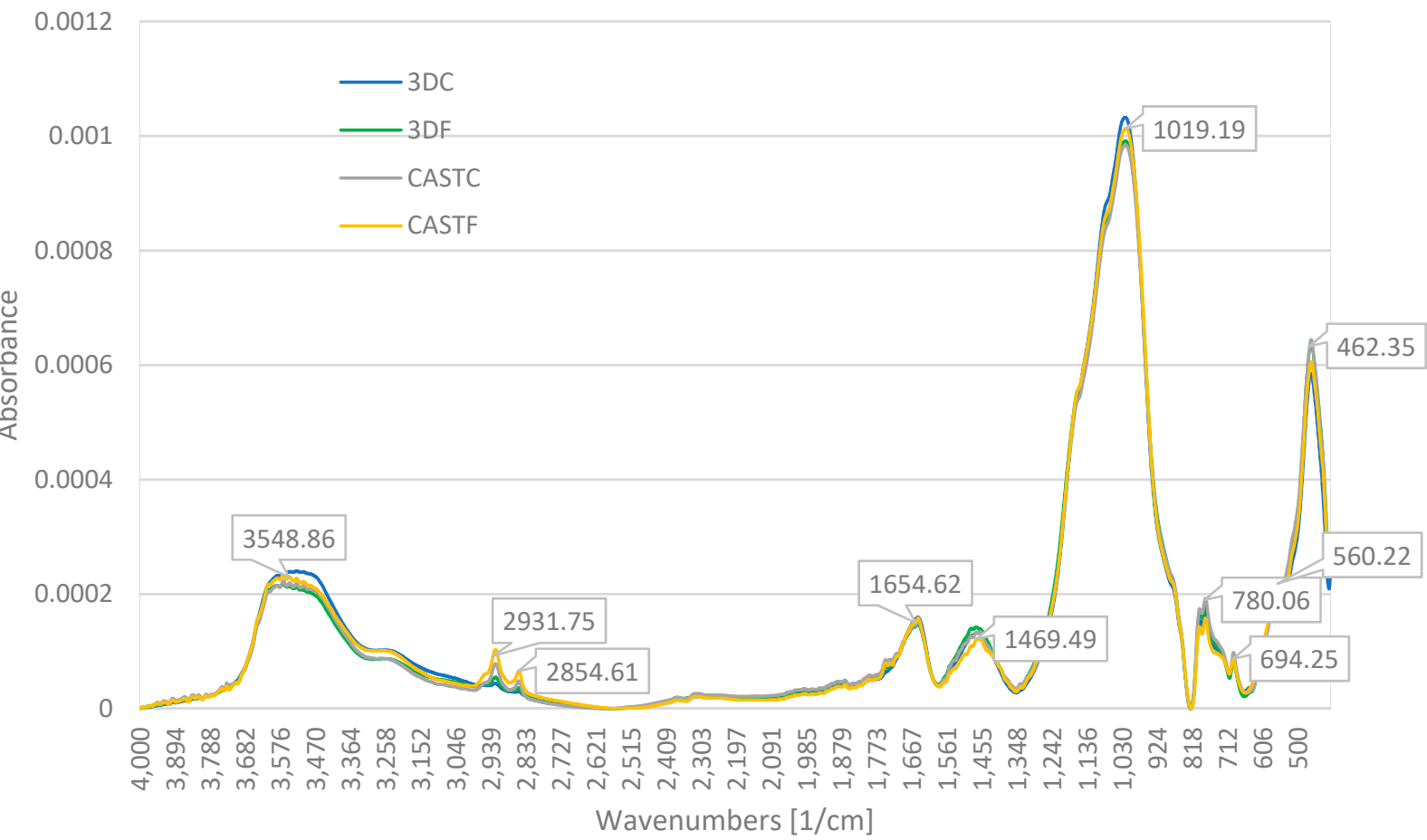

Figure 2. FT-IR for geopolymer composites.

FT-IR spectra are typical for geopolymer materials and shows bonds typical for their internal structure [5]. The peak at a wave number of $3548 \mathrm{~cm}^{-1}$ represents the stretching vibration of the free O-H group. Similarly, the peak at $1640 \mathrm{~cm}^{-1}$ represents the bending vibration of hydrogen-bonded $\mathrm{O}-\mathrm{H}$ group (absorbed water) and the peak at wavenumbers of 2931 represents the stretching vibration of hydrogen-bonded O-H group [5,45,46]. It could indicate a small amount of molecular water. The peak at $2854 \mathrm{~cm}^{-1}$ could represent $\mathrm{C}-\mathrm{H}$ bond $[4,47]$.

The peaks at a wave number of 1469 characterize the stretching vibration of the $\mathrm{C}-\mathrm{O}$ bond, which could be related to sodium bicarbonate- $\mathrm{Na}_{2} \mathrm{CO}_{3}[48,49]$.

The broad and strongest peak at a wavenumber of $1019 \mathrm{~cm}^{-1}$ is the asymmetric stretching vibration of the $\mathrm{Si}-\mathrm{O}-\mathrm{T}$ bond (where $\mathrm{T}$ denotes $\mathrm{Si}$ or $\mathrm{Al}$ ) [5,50-52]. It is probably associated with asymmetric stretching vibrations and also with $\mathrm{Si}-\mathrm{O}(\mathrm{Si})$. The peak at about $460 \mathrm{~cm}^{-1}$ connected with bending vibrations $\mathrm{Si}-\mathrm{O}(\mathrm{Si})$ presented in silicate tetrahedra [52,53]. The peaks at 780 and $694 \mathrm{~cm}^{-1}$ represent the crystalline phase of quartz components $[6,52,53]$. 
The analysis shows that all geopolymer composites have a similar internal structure, consisting of free $\mathrm{O}-\mathrm{H}$, hydrogen bonded $\mathrm{O}-\mathrm{H}, \mathrm{C}-\mathrm{O}, \mathrm{Si}-\mathrm{O}-\mathrm{Al}$ and $\mathrm{Si}-\mathrm{O}-\mathrm{Si}$ as well as the crystalline phase of quartz (Table 2). FT-IR clearly shows the presence of aluminum silicates and/or aluminosilicates in geopolymers.

Table 2. Summarising the results for FT-IR for the geopolymer composites.

\begin{tabular}{ccccc}
\hline No & Main Peak & Maximum & Local Maximum & Bounding \\
\hline 1 & $3696-3132$ & 3548 & - & O-H \\
2 & - & 2931 & - & O-H \\
3 & - & 2854 & - & C-H \\
4 & $1754-1581$ & 1654 & - & H-O-H \\
5 & $1581-1357$ & 1469 & - & C-O \\
6 & $1357-821$ & 1019 & 694 & Si-O-Al or \\
7 & $821-657$ & 780 & 560 & Si-O-Si \\
8 & $657-404$ & 462 & & Si-O-Si $(\mathrm{Si})$ \\
\hline
\end{tabular}

2.3. Chemical and Mineralogical Composition with the Use Spectroscopy (XRD-X-ray Diffraction and XRF-X-ray Fluorescence)

The elemental and oxide compositions investigated by XRF are presented in Tables 3 and 4. They have been compared with the composition of main raw materials—sand and fly ash.

Table 3. The elemental composition.

\begin{tabular}{ccccccc}
\hline Element & Fly Ash & Sand & 3DC & CASTC & 3DF & CASTF \\
\hline $\mathrm{O}$ & 47.177 & 51.197 & 45.480 & 45.458 & 45.679 & 46.035 \\
$\mathrm{Si}$ & 22.693 & 40.902 & 25.435 & 25.575 & 25.889 & 26.645 \\
$\mathrm{Al}$ & 16.816 & 3.1760 & 9.7722 & 9.6359 & 9.8108 & 9.6718 \\
$\mathrm{Na}$ & 1.5975 & 0.86054 & 7.6957 & 7.2118 & 6.9284 & 6.5153 \\
$\mathrm{Fe}$ & 4.2531 & 1.0207 & 4.1249 & 4.4371 & 4.1543 & 3.9194 \\
$\mathrm{Ca}$ & 2.1660 & 0.89557 & 3.1752 & 3.3382 & 3.0991 & 3.0672 \\
$\mathrm{~K}$ & 2.1515 & 1.3310 & 2.0509 & 2.1184 & 2.2392 & 2.0693 \\
$\mathrm{Mg}$ & 1.1472 & 0.23151 & 0.74137 & 0.72434 & 0.75079 & 0.74537 \\
$\mathrm{Ti}$ & 0.65890 & 0.15722 & 0.64831 & 0.65113 & 0.60643 & 0.57807 \\
$\mathrm{~S}$ & 0.75313 & 0.036447 & 0.31958 & 0.27343 & 0.26437 & 0.23894 \\
$\mathrm{P}$ & 0.21729 & 0.035690 & 0.13598 & 0.11976 & 0.13932 & 0.12317 \\
$\mathrm{Ba}$ & 0.09688 & 0.037588 & 0.090645 & 0.11115 & 0.09866 & 0.085606 \\
$\mathrm{Mn}$ & 0.068042 & 0.015097 & 0.058950 & 0.078441 & 0.077765 & 0.059950 \\
$\mathrm{Cl}$ & 0.034838 & 0.012234 & 0.056550 & 0.059827 & 0.057638 & 0.046814 \\
$\mathrm{Sr}$ & 0.048700 & 0.017301 & 0.049155 & 0.051727 & 0.051172 & 0.045803 \\
$\mathrm{Cr}$ & 0.020727 & 0.060160 & 0.027897 & 0.030106 & 0.037666 & 0.040166 \\
$\mathrm{Zr}$ & 0.024358 & 0.014688 & 0.024719 & 0.030090 & 0.028394 & 0.025463 \\
$\mathrm{Nd}$ & - & - & 0.017149 & - & - & - \\
$\mathrm{Zn}$ & 0.023821 & - & 0.016475 & 0.022908 & 0.016359 & 0.022489 \\
$\mathrm{Cu}$ & 0.013335 & - & 0.016279 & 0.015339 & 0.015605 & 0.011612 \\
$\mathrm{~Pb}$ & 0.014866 & - & 0.016108 & 0.013911 & 0.017128 & 0.014254 \\
$\mathrm{Ni}$ & 0.010272 & - & 0.014821 & 0.013401 & 0.012586 & 0.013197 \\
$\mathrm{Rb}$ & 0.013641 & - & 0.013645 & 0.015159 & 0.014523 & 0.013760 \\
$\mathrm{Co}$ & - & - & - & 0.015016 & 0.011711 & 0.011752 \\
\hline
\end{tabular}


Table 4. The oxide composition.

\begin{tabular}{|c|c|c|c|c|c|c|}
\hline Oxide & FLY ASH & Sand & $3 \mathrm{DC}$ & CASTC & $3 \mathrm{DF}$ & CASTF \\
\hline $\mathrm{Na}_{2} \mathrm{O}$ & 2.153 & 1.160 & 10.374 & 9.721 & 9.339 & 8.782 \\
\hline $\mathrm{MgO}$ & 1.902 & 0.384 & 1.229 & 1.201 & 1.245 & 1.236 \\
\hline $\mathrm{Al}_{2} \mathrm{O}_{3}$ & 31.773 & 6.001 & 18.464 & 18.207 & 18.537 & 18.275 \\
\hline $\mathrm{SiO}_{2}$ & 48.548 & 87.502 & 54.453 & 54.713 & 55.386 & 57.003 \\
\hline $\mathrm{P}_{2} \mathrm{O}_{5}$ & 0.498 & 0.082 & 0.312 & 0.274 & 0.319 & 0.282 \\
\hline $\mathrm{SO}_{3}$ & 1.881 & 0.091 & 0.798 & 0.683 & 0.660 & 0.597 \\
\hline $\mathrm{K}_{2} \mathrm{O}$ & 2.592 & 1.603 & 2.471 & 2.552 & 2.697 & 2.493 \\
\hline $\mathrm{CaO}$ & 3.031 & 1.253 & 4.443 & 4.671 & 4.336 & 4.292 \\
\hline $\mathrm{TiO}_{2}$ & 1.099 & 0.262 & 1.081 & 1.086 & 1.012 & 0.964 \\
\hline $\mathrm{Cr}_{2} \mathrm{O}_{3}$ & 0.030 & 0.088 & 0.041 & 0.044 & 0.055 & 0.059 \\
\hline $\mathrm{MnO}$ & 0.088 & 0.019 & 0.076 & 0.101 & 0.100 & 0.077 \\
\hline $\mathrm{Fe}_{2} \mathrm{O}_{3}$ & 6.081 & 1.459 & 5.898 & 6.344 & 5.939 & 5.604 \\
\hline $\mathrm{NiO}$ & 0.013 & - & 0.019 & 0.017 & 0.016 & 0.017 \\
\hline $\mathrm{CuO}$ & 0.017 & - & 0.020 & 0.019 & 0.020 & 0.015 \\
\hline $\mathrm{ZnO}$ & 0.030 & - & 0.021 & 0.029 & 0.020 & 0.028 \\
\hline $\mathrm{Rb}_{2} \mathrm{O}$ & 0.015 & - & 0.015 & 0.017 & 0.016 & 0.015 \\
\hline $\mathrm{SrO}$ & 0.058 & 0.020 & 0.058 & 0.061 & 0.061 & 0.054 \\
\hline $\mathrm{ZrO}_{2}$ & 0.033 & 0.020 & 0.033 & 0.041 & 0.038 & 0.034 \\
\hline $\mathrm{BaO}$ & 0.108 & 0.042 & 0.101 & 0.124 & 0.110 & 0.096 \\
\hline $\mathrm{Nd}_{2} \mathrm{O}_{3}$ & - & - & 0.020 & - & - & - \\
\hline $\mathrm{PbO}$ & 0.016 & - & 0.017 & 0.015 & 0.018 & 0.015 \\
\hline $\mathrm{Co}_{3} \mathrm{O}_{4}$ & - & - & - & 0.020 & 0.016 & 0.016 \\
\hline $\mathrm{Cl}$ & 0.035 & 0.012 & 0.057 & 0.060 & 0.058 & 0.047 \\
\hline
\end{tabular}

As expected, the main elements of the composite structure are: oxygen $(\mathrm{O})$, silica $(\mathrm{Si})$, and aluminum $(\mathrm{Al})$. These elements come from raw materials used and are the basic element for creating the structure of the geopolymer. The reinforcement and the method of the production do not have any significant influence on the elemental characterization. All compositions include sodium $(\mathrm{Na})$, which comes from the sodium promoter that is used during the manufacturing process. The analysis also show the small amount of iron (Fe) and calcium (Ca) in the material (Table 3).

The oxide composition, presented in Table 4, is essential for geopolymerization process.

The main oxides presented in the structure are: alumina- $\mathrm{Al}_{2} \mathrm{O}_{3}$ and silica- $\mathrm{SiO}_{2}$. This is typical for geopolymer materials. Moreover, the composite includes significant amounts of $\mathrm{Fe}_{2} \mathrm{O}_{3}, \mathrm{Na}_{2} \mathrm{O}$ and $\mathrm{CaO}$. The obtained data are coherent with the applied raw materials; in particular, they confirmed the applied fly ash has a composition relevant for the class $\mathrm{F}$. This class is characterized by a high percentage of silica $\left(\mathrm{SiO}_{2}\right)$, alumina $\left(\mathrm{Al}_{2} \mathrm{O}_{3}\right)$, and iron oxide $\left(\mathrm{Fe}_{2} \mathrm{O}_{3}\right)-$ min. $70 \%$ and, in addition, low percentage of calcium oxide $(\mathrm{CaO})-\max .4 \%$ [54,55]. The compositions achieved mixtures according to their oxide composition are very similar. There is no significant differences between compositions and method of production. The alumina- $\mathrm{Al}_{2} \mathrm{O}_{3}$ is in range up 18.207 to $18.537 \%$ and the silica- $\mathrm{SiO}_{2}$ between 54.453 and $57.003 \%$. The weight ratios crucial oxides such as: $\mathrm{SiO}_{2} / \mathrm{Al}_{2} \mathrm{O}_{3}, \mathrm{CaO} / \mathrm{Al}_{2} \mathrm{O}_{3}, \mathrm{CaO} / \mathrm{SiO}_{2}$, $\mathrm{SiO}_{2} / \mathrm{Na}_{2} \mathrm{O}$ and $\mathrm{Al}_{2} \mathrm{O}_{3} / \mathrm{Na}_{2} \mathrm{O}$ are suitable for geopolimerization and are similar for all compositions analyzed [56,57]. Additionally, the low amount of $\mathrm{CaO}$ is positive for a geopolymerization. It supports a longer time taken for material bounding thanks to the creation of a 3D structure. This kind of structure gives the geopolymers a suitable resistance to environmental conditions $[54,58,59]$. The advantages can also be seen with some amount of content iron oxide $\left(\mathrm{Fe}_{2} \mathrm{O}_{3}\right)$. Some research shows that it should positively influence 3D structure $[54,55,60]$ and could be important in high temperature applications [61].

The investigation also involved the determination of the mineralogical structure by XRD. All compositions have a similar structure (Figure 3).

Identified phases are quartz, mullite, hematite, magnetite, anhydrite, albite, and sylimanite. The first two large peaks came from quartz. A significant amount of quartz is associated with the use of sand as an aggregate. The third and fourth peaks, which 
are slightly visible at Figure $3 d$, came from albite and anhydrite. These minerals are also popular in the mineral composition of geopolymers [62,63]. The peaks at about 60 are connected with the presence of mullite. The amount of this mineral is slightly different with all of the samples presented. The double peak before 70 is connected to quartz. The other peaks are also connected with the minerals or hematite presented (peak around 43). The mineralogical composition is slightly different for the presented samples, but the variations in results are mainly connected with the amounts of particular minerals in the composition. There should not be a significant influence on the material properties. Among them, there are crystalline as well as amorphous phases. The typical crystalline phases for geopolymer composites are quartz (related to silicon dioxide), mullite, hematite, albite, and anhydrite [54,62]. The curves also indicate the presence of an amorphous phase (indicated by diffuse halo/the curves have a broad hump) $[62,63]$.

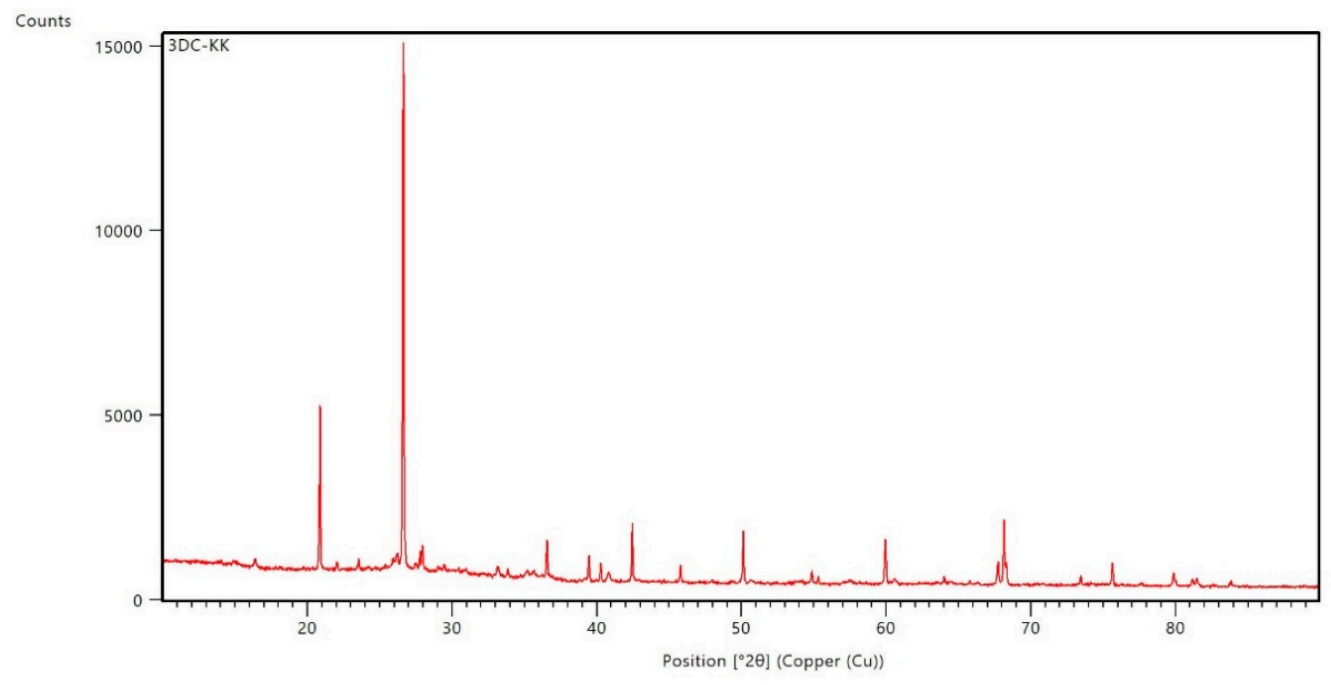

(a)

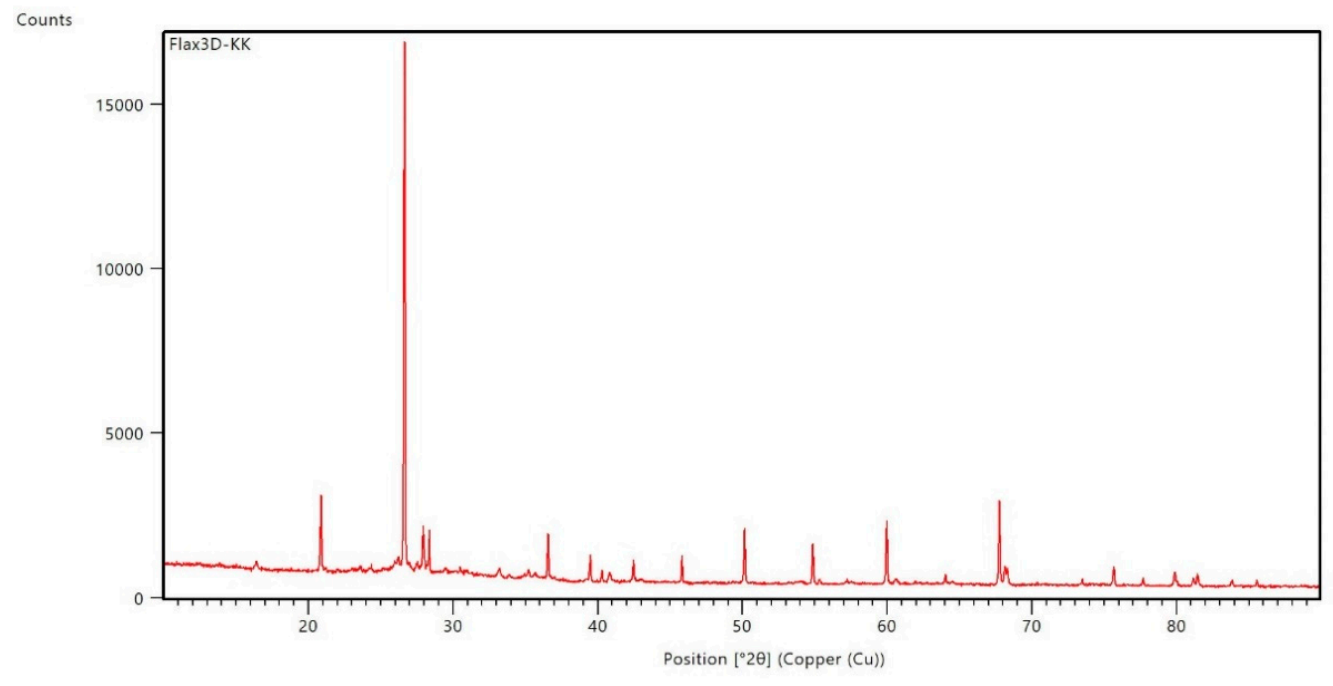

(b)

Figure 3. Cont. 


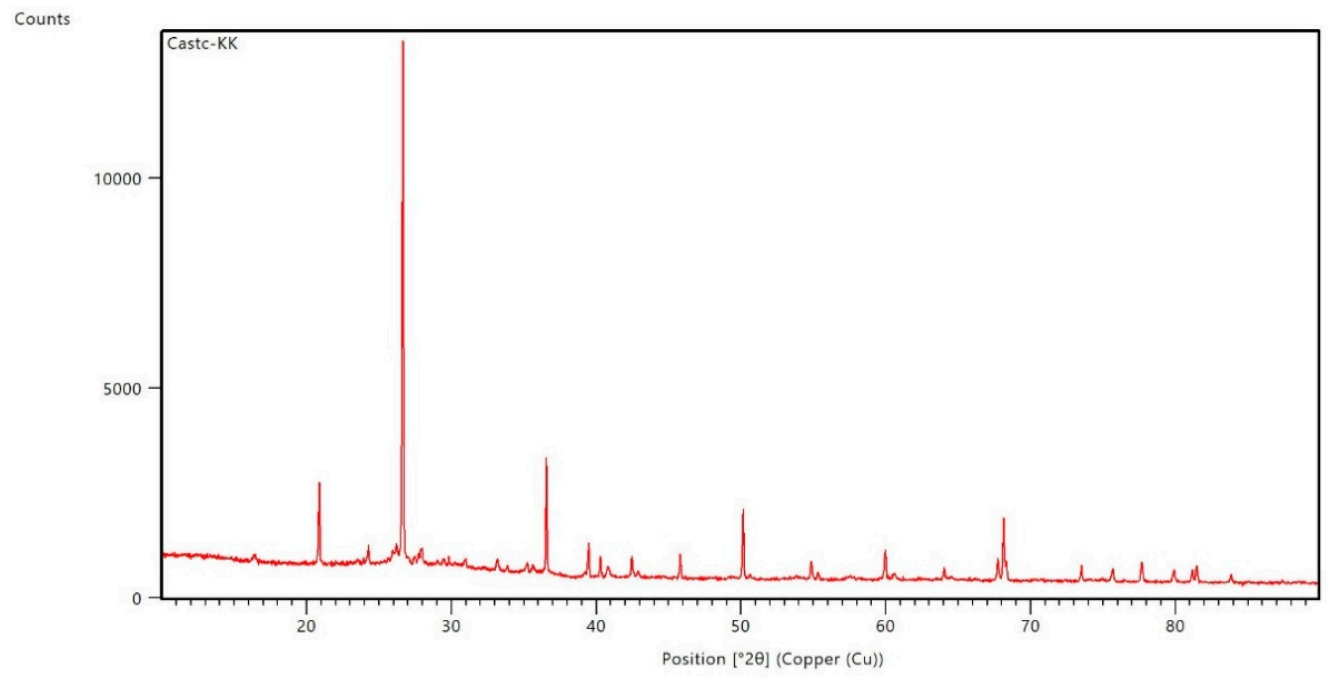

(c)

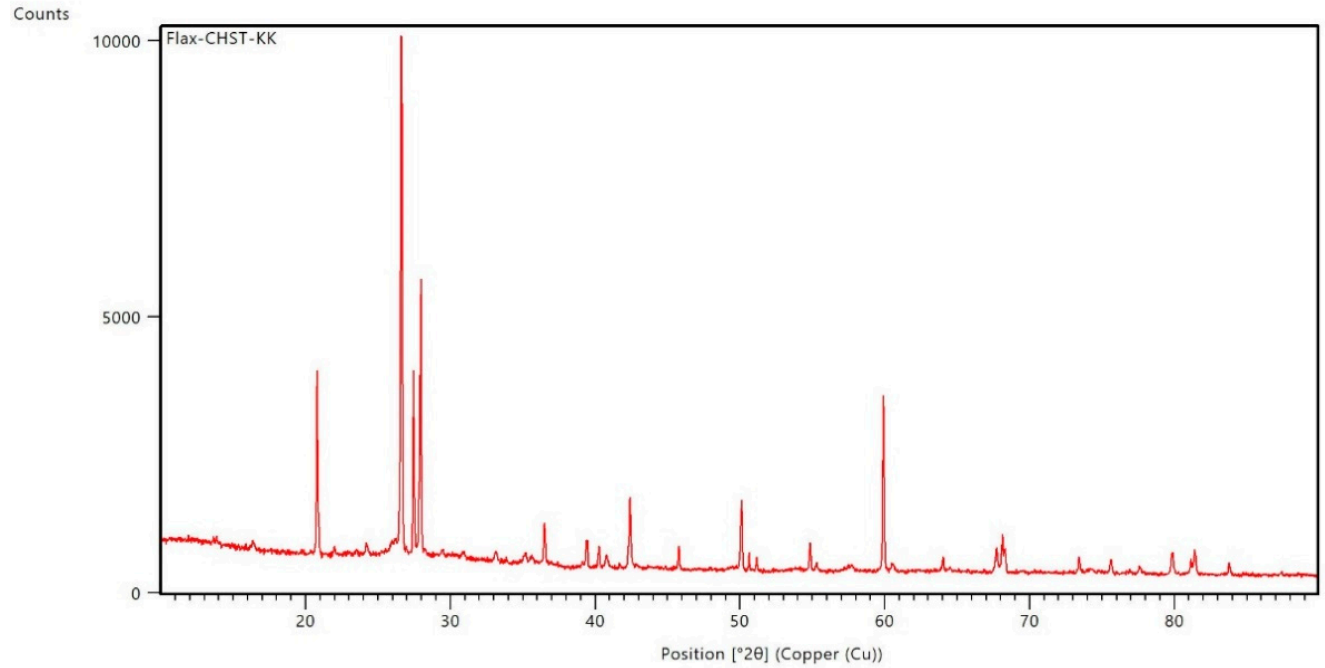

(d)

Figure 3. The results of XRD analysis for samples: (a) 3DC; (b) 3DF; (c) CASTC; (d) CASTF.

\subsection{Nuclear Magnetic Resonance Spectroscopy (NMR)}

To confirm the typical internal structure for geopolymers and find potential differences between compositions, NMR analysis has also been provided. In contrast to geopolymers, the alkaline activated materials do not form 3D networks, but only a 2D structure. It affects the material properties, including different physicochemical and functional properties, such as resistance to chemical agents, functional properties such as fire resistance, and long-term properties, durability $[54,64]$. Wherein, the mechanical properties of alkaline activated materials could be even higher than that of geopolymers, especially in the short term [64]. At the same time, their resistance and long-term properties are usually worse [64]. The differences are usually visible in NMR microstructural studies $[65,66]$.

For geopolymer materials, the presence of $\mathrm{SiO}_{4}$ and $\mathrm{AlO}_{4}$ tetrahedrons in a threedimensional structure is crucial. The reactive aluminosilicates are dissolved, and next in the polycondensation process, the tetrahedrical structures $\left[\mathrm{SiO}_{4}\right]_{4-},\left[\mathrm{AlO}_{4}\right]_{5-}$ combine together with the corners, forming amorphous or sub-crystalline spatial aluminosilicate structures $[54,64]$. To confirm this structure, an investigation of ${ }^{27} \mathrm{Al}$ and ${ }^{29} \mathrm{Si}$ was performed for all compositions [66,67]. 
Figure 4 shows the results for all compositions produced by two different methods. There are no significant differences between the samples analyzed.

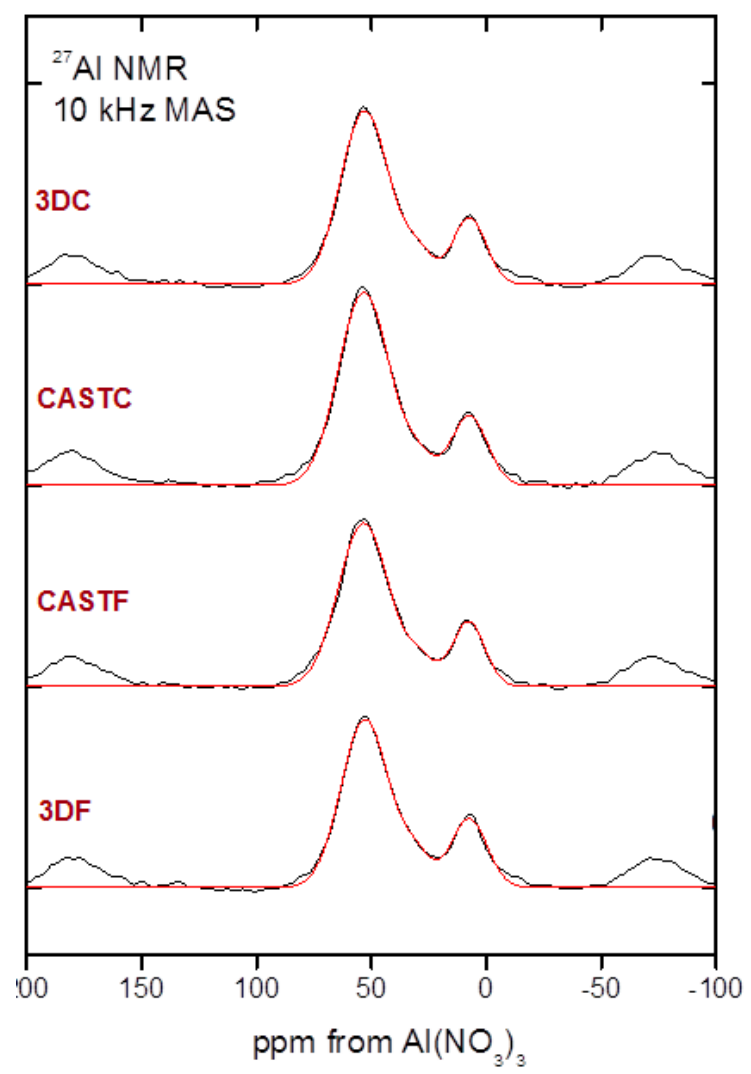

(a)

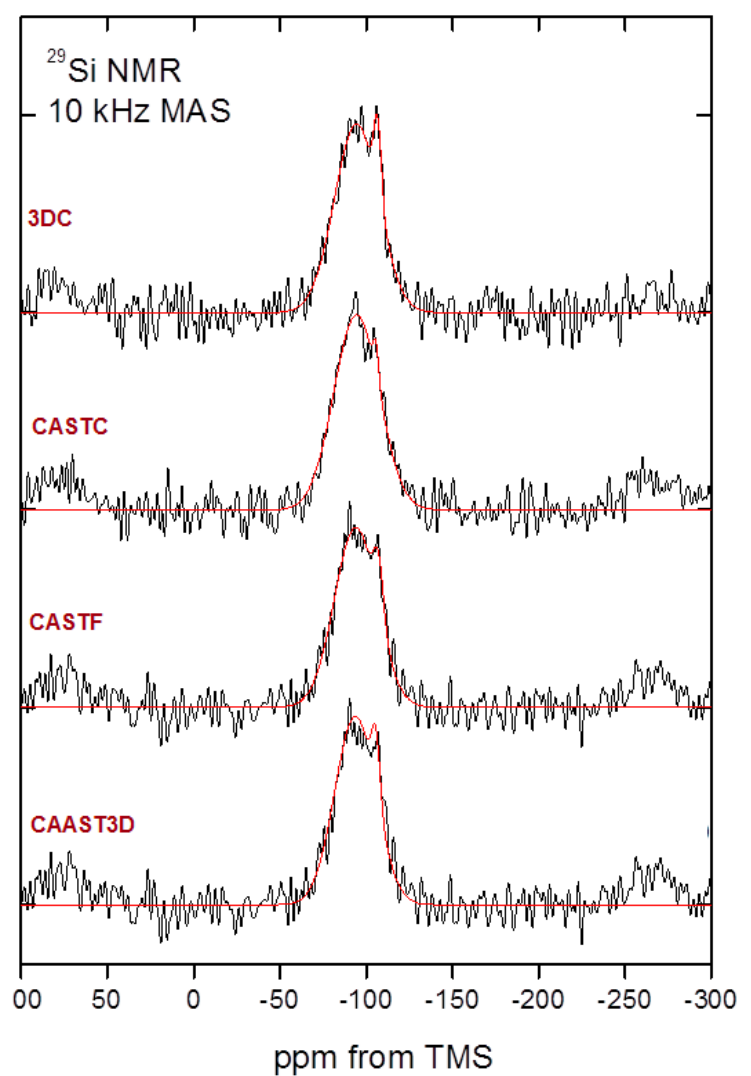

(b)

Figure 4. The results of NMR analysis for: (a) aluminum; (b) silica.

Aluminate anions, four-coordinated aluminum (with respect to oxygen) resonate at 60-80 ppm, and that in silico-aluminates, four-coordinated aluminum resonates at approximately $50 \pm 20 \mathrm{ppm}$ while six-coordinated aluminum resonates at about $0 \pm 10 \mathrm{ppm}$ from $\left[\mathrm{Al}\left(\mathrm{H}_{2} \mathrm{O}\right)_{6}\right]^{3+}[66,67]$. The ${ }^{27} \mathrm{Al}$ chemical changes, presented in Figure 4 and Table 5 , in the range of ca. $55 \mathrm{ppm}$ from $\left[\mathrm{Al}\left(\mathrm{H}_{2} \mathrm{O}\right)_{6}\right]^{3+}$ indicate that the aluminum is of the AlQ4 $(4 \mathrm{Si})$ type and is tetrahedrally coordinated. The ${ }^{29} \mathrm{Si} \mathrm{MAS}-\mathrm{NMR}$ is represented by two peaks (Figure 4). The major band at ca. $-94 \mathrm{ppm}$, is connected with the presence of a SiQ4 (2Al) unit and the second band at $-115 \mathrm{ppm}$ is related to unreacted silica-fume- $\mathrm{SiO}_{2}$ (Table 5). The second component is probably the result of sand addition [66,67].

The presented data show that all composites have a similar internal structure typical for geopolymer material.

\subsection{Atomic Force Microscope (AFM)}

Figure 5 shows the imaging of surface fragments selected for research by atomic force microscopy (AFM) in the semi-contact mode (Tapping Mode) for four samples of geopolymer composites. 
Table 5. Spectrum analysis ${ }^{27} \mathrm{Al}$ and ${ }^{29} \mathrm{Si}$ MAS-NMR.

\begin{tabular}{|c|c|c|c|c|c|c|}
\hline \multirow[b]{2}{*}{ Sample } & \multicolumn{3}{|c|}{${ }^{27}$ Al MAS-NMR } & \multicolumn{3}{|c|}{${ }^{29}$ Si MAS-NMR } \\
\hline & Position [ppm] & $\begin{array}{c}\text { Width } \\
\text { Half [ppm] }\end{array}$ & $\begin{array}{c}\text { Relative } \\
\text { Intensity [\%] }\end{array}$ & Position [ppm] & $\begin{array}{c}\text { Width } \\
\text { Half [ppm] }\end{array}$ & $\begin{array}{c}\text { Relative } \\
\text { Intensity [\%] }\end{array}$ \\
\hline \multirow{3}{*}{$3 \mathrm{DC}$} & 53.6 & 25.0 & 73 & \multirow{3}{*}{$\begin{array}{c}-94.0 \\
-106.3\end{array}$} & \multirow{3}{*}{$\begin{array}{c}30.1 \\
5.2\end{array}$} & \multirow{3}{*}{$\begin{array}{c}94 \\
6\end{array}$} \\
\hline & 30.3 & 15.6 & 7 & & & \\
\hline & $\begin{array}{c}8.2 \\
540\end{array}$ & $\begin{array}{l}17.2 \\
25.8\end{array}$ & $\begin{array}{l}20 \\
75\end{array}$ & & & \\
\hline \multirow{2}{*}{ CASTC } & $\begin{array}{l}54.0 \\
29.9\end{array}$ & $\begin{array}{l}25.8 \\
16.1\end{array}$ & $\begin{array}{c}75 \\
6\end{array}$ & \multirow{2}{*}{$\begin{array}{r}-94.0 \\
-105.3\end{array}$} & \multirow{2}{*}{$\begin{array}{c}30.9 \\
3.8\end{array}$} & \multirow{2}{*}{$\begin{array}{c}98 \\
2\end{array}$} \\
\hline & 8.2 & $\begin{array}{l}16.1 \\
18.5\end{array}$ & $\begin{array}{c}0 \\
19\end{array}$ & & & \\
\hline \multirow{3}{*}{ CASTF } & 54.2 & 25.8 & 74 & \multirow{3}{*}{$\begin{array}{c}-93.6 \\
-108.2\end{array}$} & \multirow{3}{*}{$\begin{array}{c}29.1 \\
6.6\end{array}$} & \multirow{3}{*}{$\begin{array}{c}94 \\
6\end{array}$} \\
\hline & 29.5 & 15.5 & 7 & & & \\
\hline & 8.6 & 16.6 & 19 & & & \\
\hline \multirow{3}{*}{$3 \mathrm{DF}$} & 53.6 & 24.2 & 70 & \multirow{3}{*}{$\begin{array}{c}-93.3 \\
-105.3\end{array}$} & \multirow{3}{*}{$\begin{array}{c}28.0 \\
5.6\end{array}$} & \multirow{3}{*}{$\begin{array}{c}94 \\
6\end{array}$} \\
\hline & 31.3 & 16.1 & 8 & & & \\
\hline & 8.4 & 18.5 & 22 & & & \\
\hline
\end{tabular}

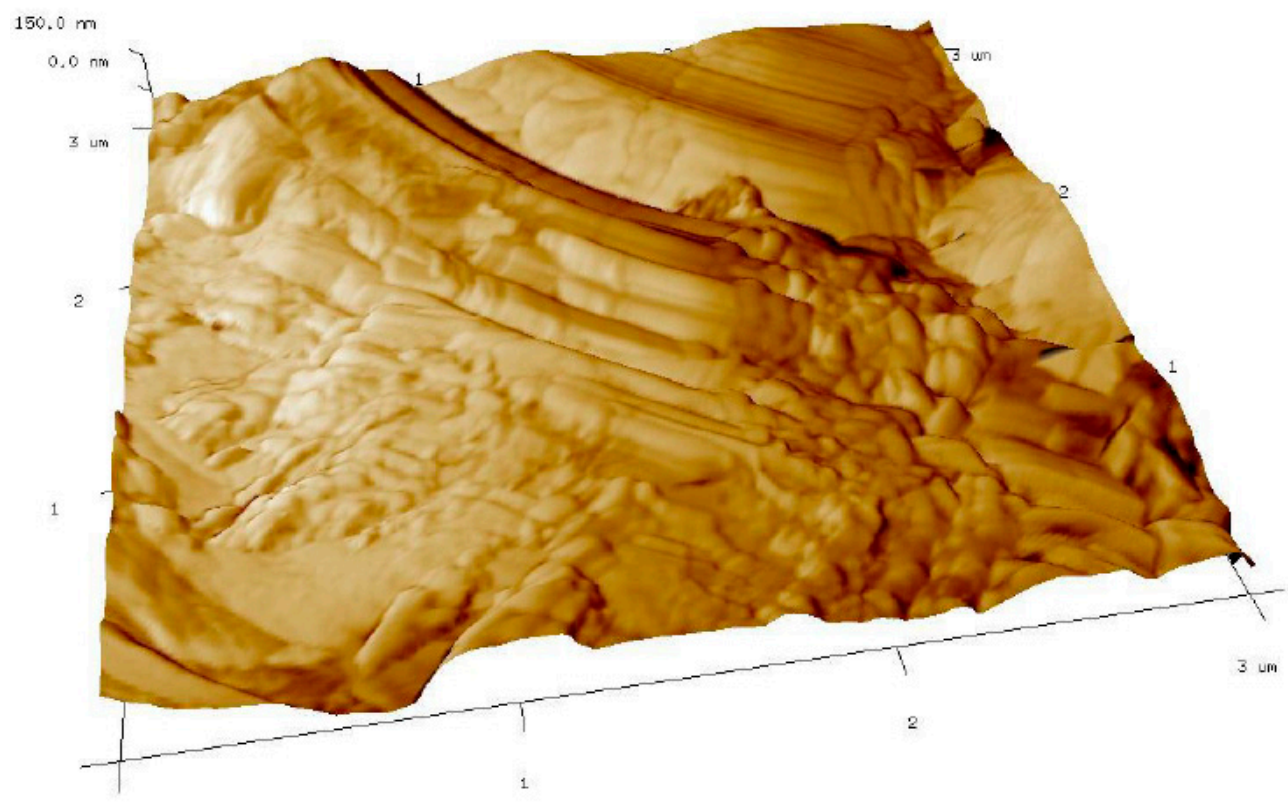

(a)

Figure 5. Cont. 


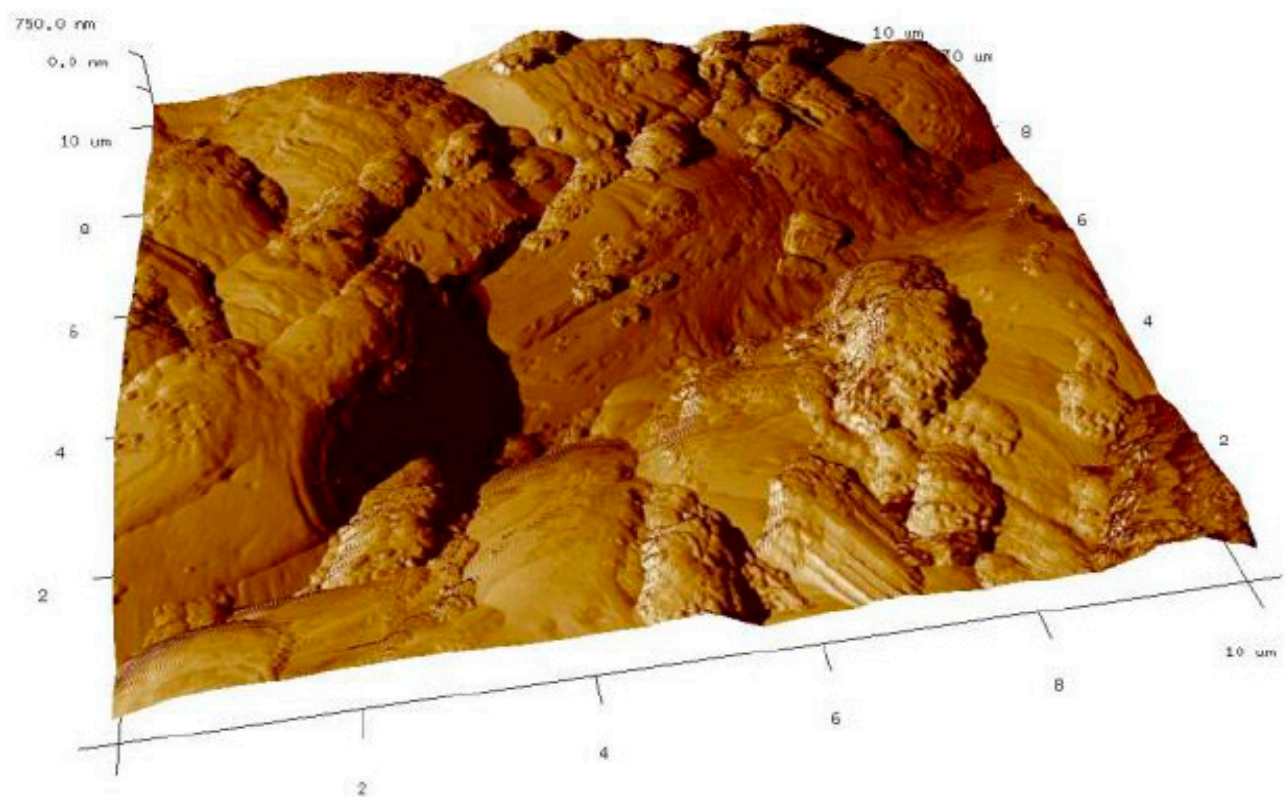

(b)

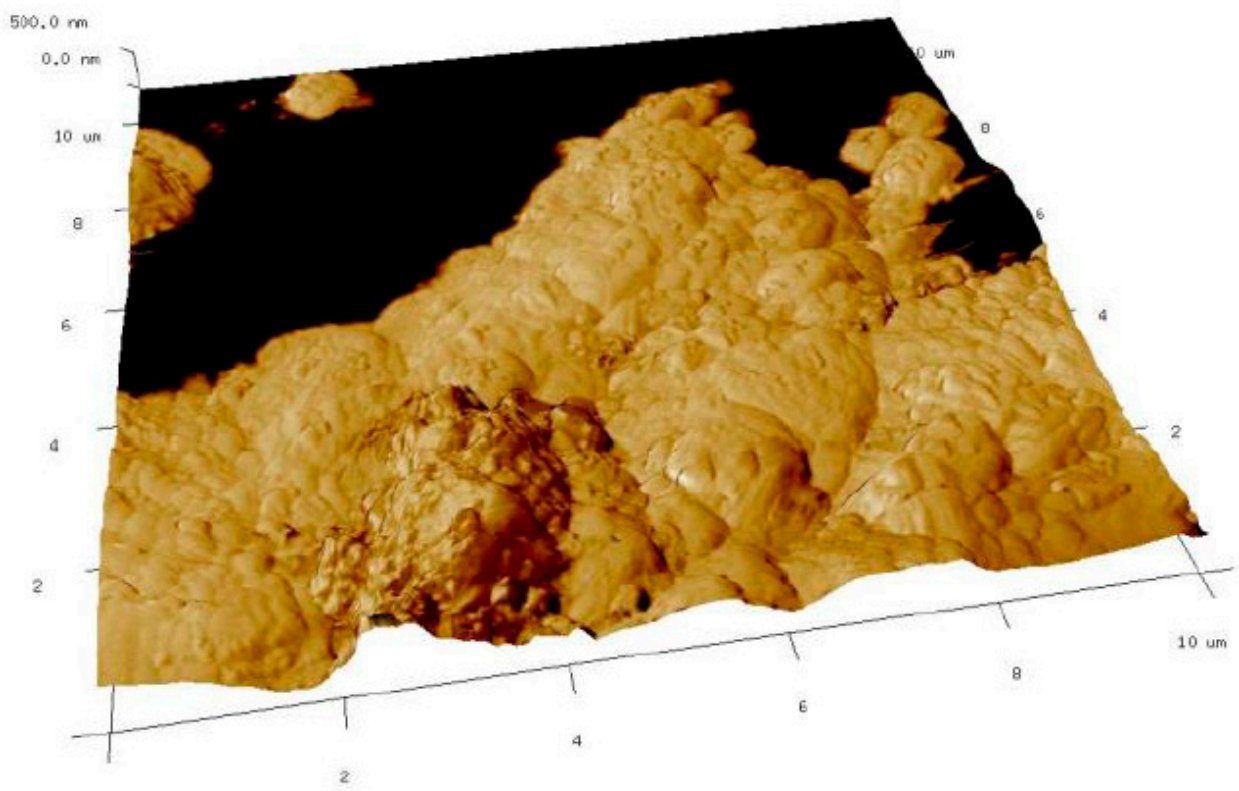

(c)

Figure 5. Cont. 


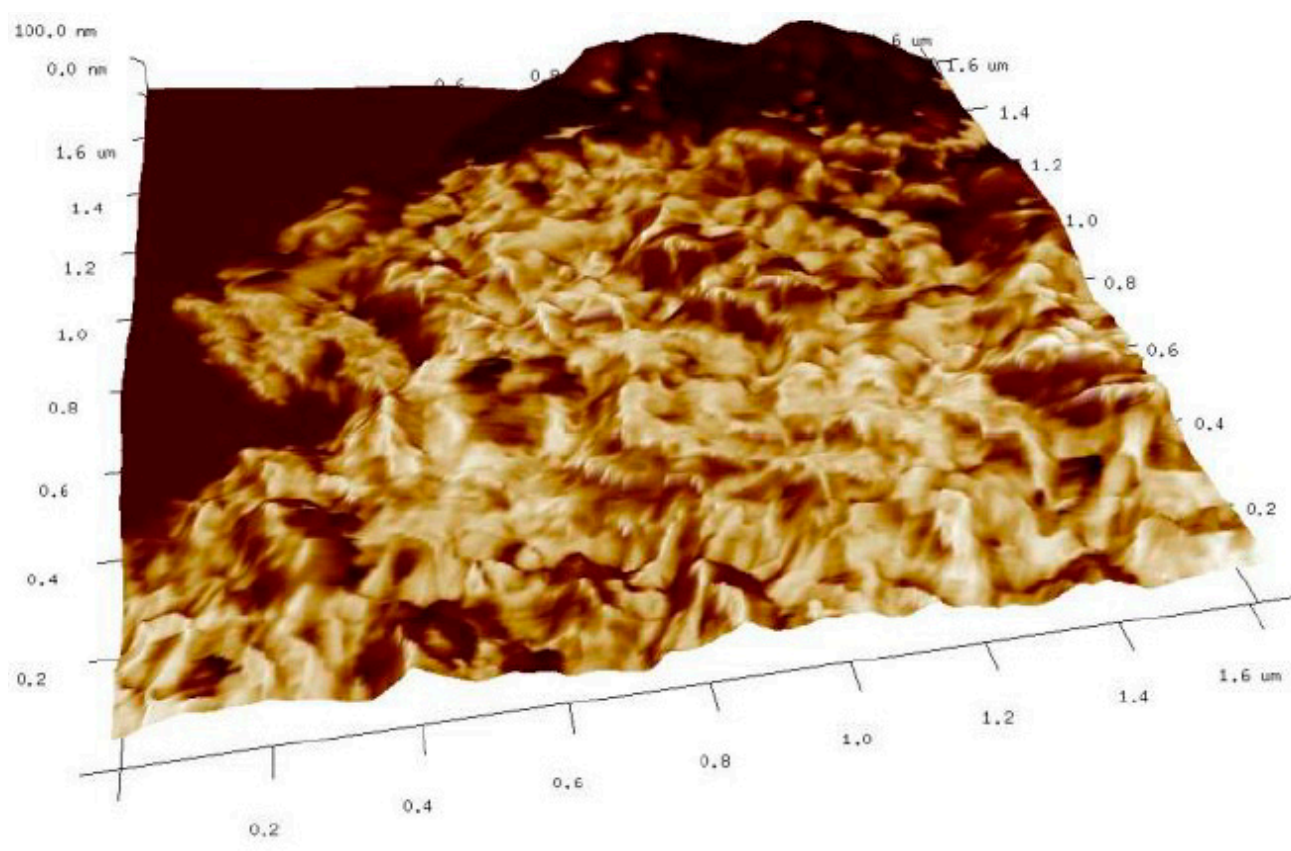

(d)

Figure 5. Phase contrast imaging of fiber surface topography in AMF: (a) 3DC; (b) 3DF; (c) CASTC; (d) CASTF.

The parts of the fibers are visible as a dark-colored phase, and the light-colored phase is a geopolymer material that covers the fiber. The observations show that the CASTC sample has large surfaces of fibers without geopolymer particles. The CASTF sample has small surfaces of the fibers, which are without any geopolymer particles. In the other two samples, 3DC and 3DF, only the fibers covered with geopolymer particles are visible. The entire surface of the fibers is covered; in the phase image of these composites, there are no differences in the phase shift on the surface of the samples. A similar effect may be due to the presence of a different type of fiber in the composite than carbon fibers.

The AMF seems to show better coherence of the geopolymer made in additive technology to the reinforcement. The surface of the fibers is more evenly covered than in casted samples. However, this kind of test is provided on very small samples, and they have a qualitative nature. The results obtained do not explain the differences in mechanical properties between the composites.

\subsection{Confocal Microscopy}

Observations on the breakthroughs of the samples were provided. They allow the microscopy pictures to be obtained, as well as the information about the surface in larger scale than AMF. Thanks to confocal microscopy, is was possible to observe the material structure in the scale between nano-dimensions (AMF) milliammeter scale (observations with the naked eye). These observations cover the investigation of the surface on a micrometer scale. The confocal microscopy investigation was supplementary to scanning microscopy and allows the 2D structure to be received on the surface topology. This observations were carried out in a smaller magnification in comparison to the presented SEM images for better visibility of fibers distribution. Microscopy observations show the differences between the fiber distributions (Figure 6). The carbon fibers, independent of the production method, have a larger tendency to create the agglomerations. 


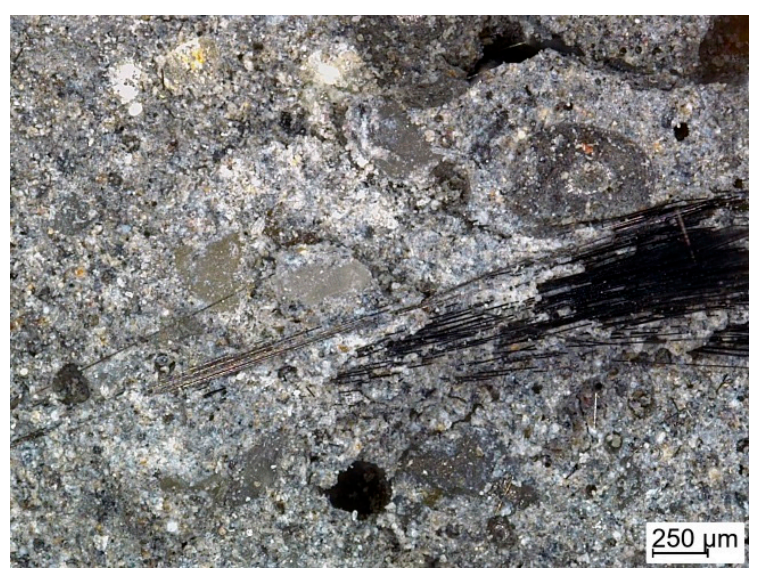

(a)

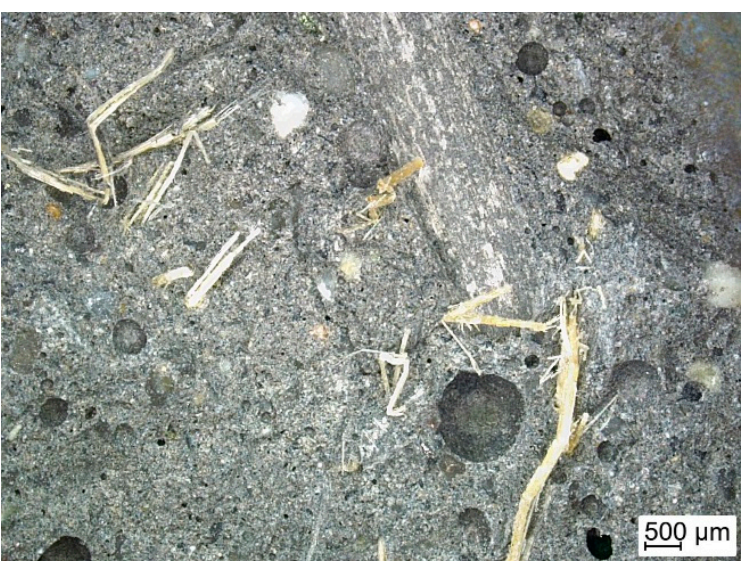

(b)

Figure 6. Structure of the composites reinforced with: (a) carbon fiber; (b) flax fiber.

Figure 7 presents the surface of the breakthrough of the composite with the surface profile. The distribution the fibers in the figure is even in this fragment. The fibers are clearly visible on the surface of the material (Figure $7 \mathrm{~b}$ ).

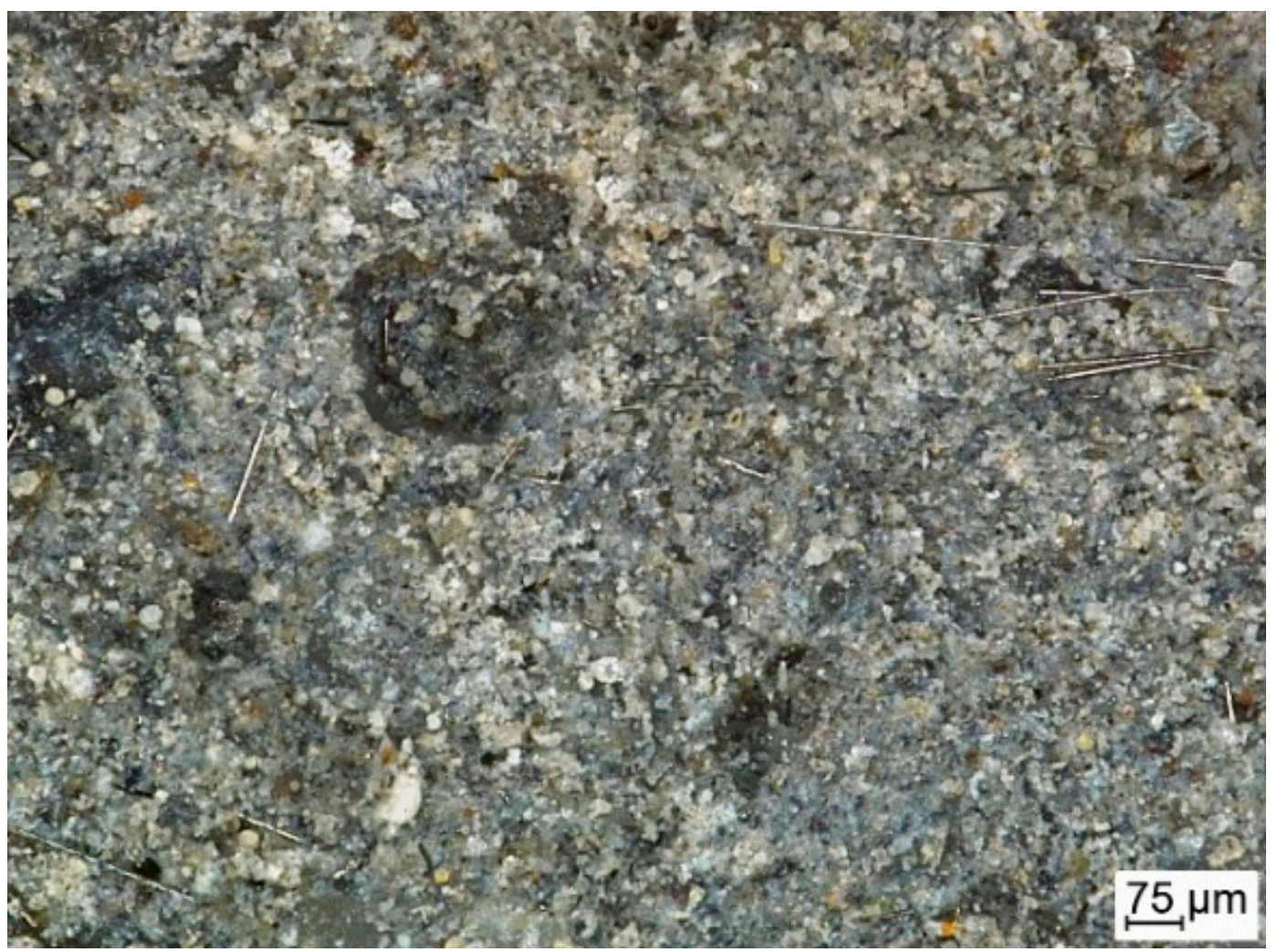

(a)

Figure 7. Cont. 


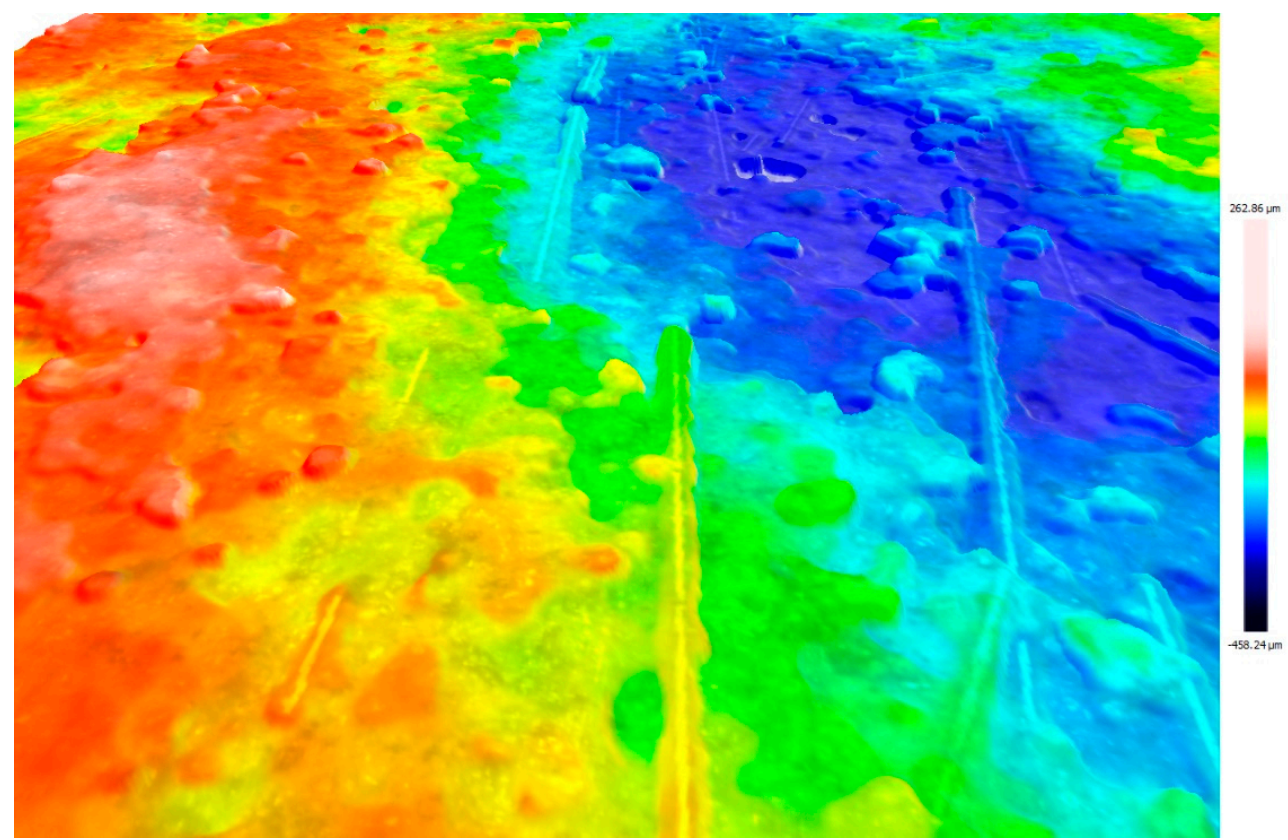

(b)

Figure 7. The structure of the carbon fiber reinforced composites: (a) structure of the composites and (b) surface profile.

Additionally, the surface profile was measured for the chosen area. Figure 8 shows the carbon fiber-reinforced surface profile of the carbon fiber-reinforced composite made by simulation of additive technology. In the profile curve, there are two peaks that give information about the height difference between the surface and the fibers. It also allows one to compare the relatively small width of the fiber with its height above the surface of the composite in the profile curve.

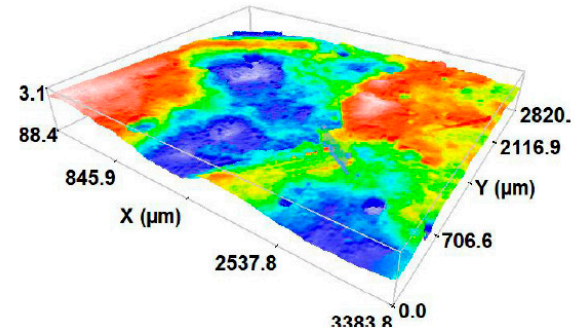

$33838^{\times 0.0}$

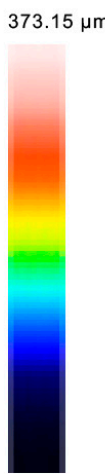

$-488.43 \mu \mathrm{m}$

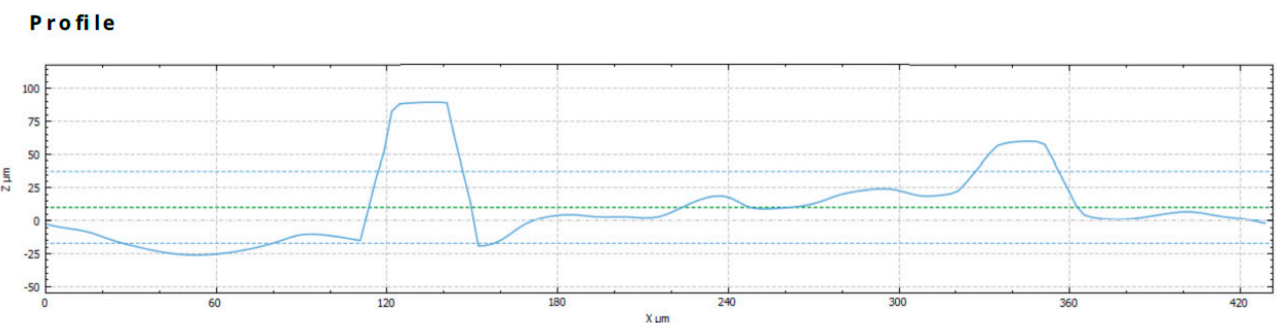

Figure 8. 3D confocal microscopy images and profile curve of the carbon fiber reinforced composite made by simulation of additive technology. 
Figure 9 presents the surface profile of the composite reinforced with flax fiber and made by simulation of additive technology. The profile curve has a slightly different character than in the case of carbon fiber. It is rougher. The single fiber is also larger in size than the single carbon fiber, and the height difference is greater (Figure 9).

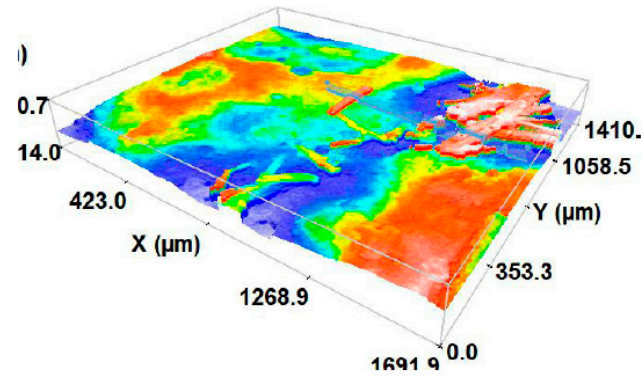

$16919^{* 0.0}$

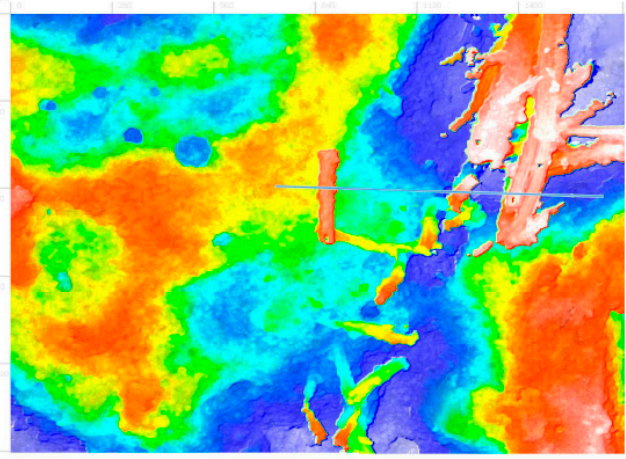

$620.73 \mu \mathrm{m}$

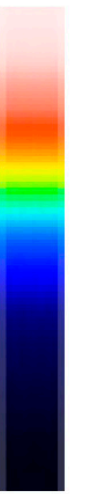

$-713.98 \mu \mathrm{m}$

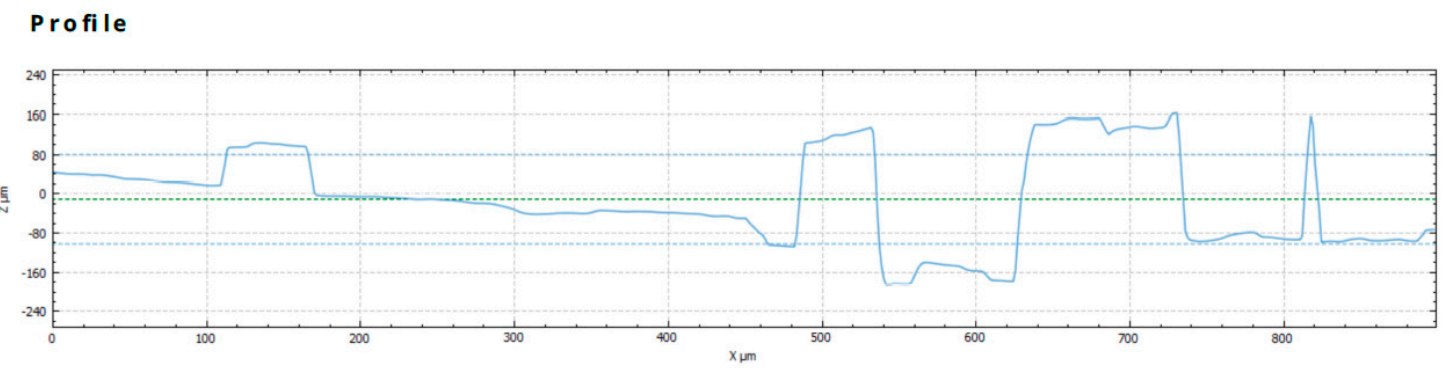

Figure 9. 3D confocal microscopy images and profile curve of the reinforced composite with flax fiber and made by simulation of additive technology.

The observations by confocal microscopy did not reveal significant differences between the samples produced by different methods.

\subsection{Microstructure Investigations with the Use of Scanning Electron Microscope (SEM)}

Scanning electron microscope (SEM) research was performed for all composites at different magnifications for the fiber-reinforced composites and for the different methods of production. Figures 10-14 show the microstructure of the samples reinforced with carbon and flax fibers. There is lack of differences between the casted samples and those made by simulation of additive technology. There is also a lack of significant differences in all samples in the microstructure of the matrix material.

In Figures 10 and 11, the microstructure of the material reinforced with carbon fibers is depicted.

Figure 10 shows the microstructure where the agglomeration of the carbon fibers is presented. The agglomeration of carbon fibers were previously reported in the literature [44]. It is a consequence of the form of the fibers that are delivered in the form of "small flakes" that are an agglomeration of single fibers. Despite the fact that the flakes are evenly distributed in the volume of the material, there are agglomerations of single fibers in it. This could have a negative influence on the mechanical properties $[44,68,69]$.

The investigation does not confirm the cohesion of the carbon fibers and the geopolymer matrix (Figure 11). The void between the fiber and the matrix is visible. This is probably the main reason that the composites with carbon fibers have worse mechanical properties than those reinforced with flax fiber. 


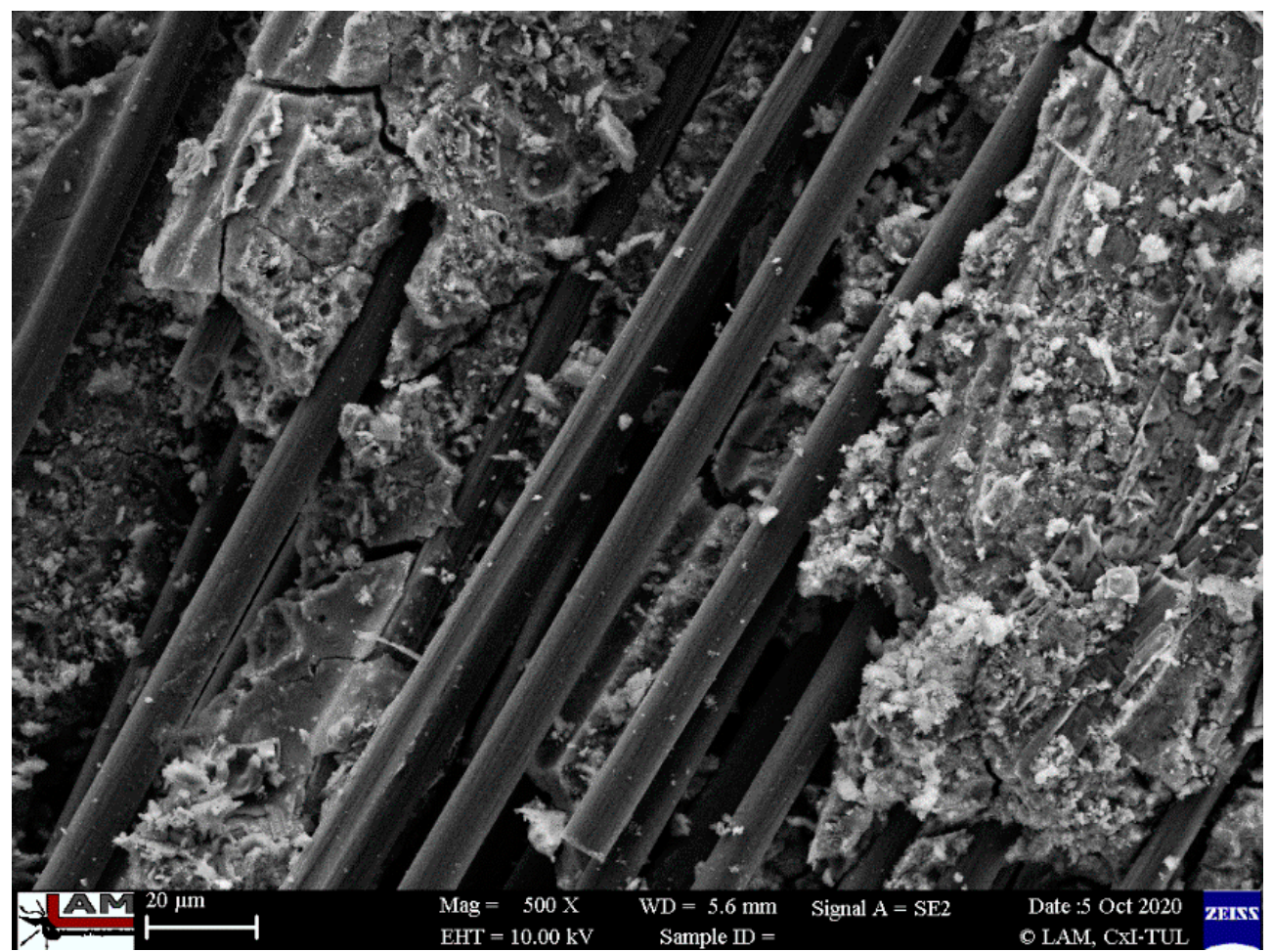

Figure 10. Microstructure of the cast samples reinforced with carbon fiber with visible fibers agglomerations.

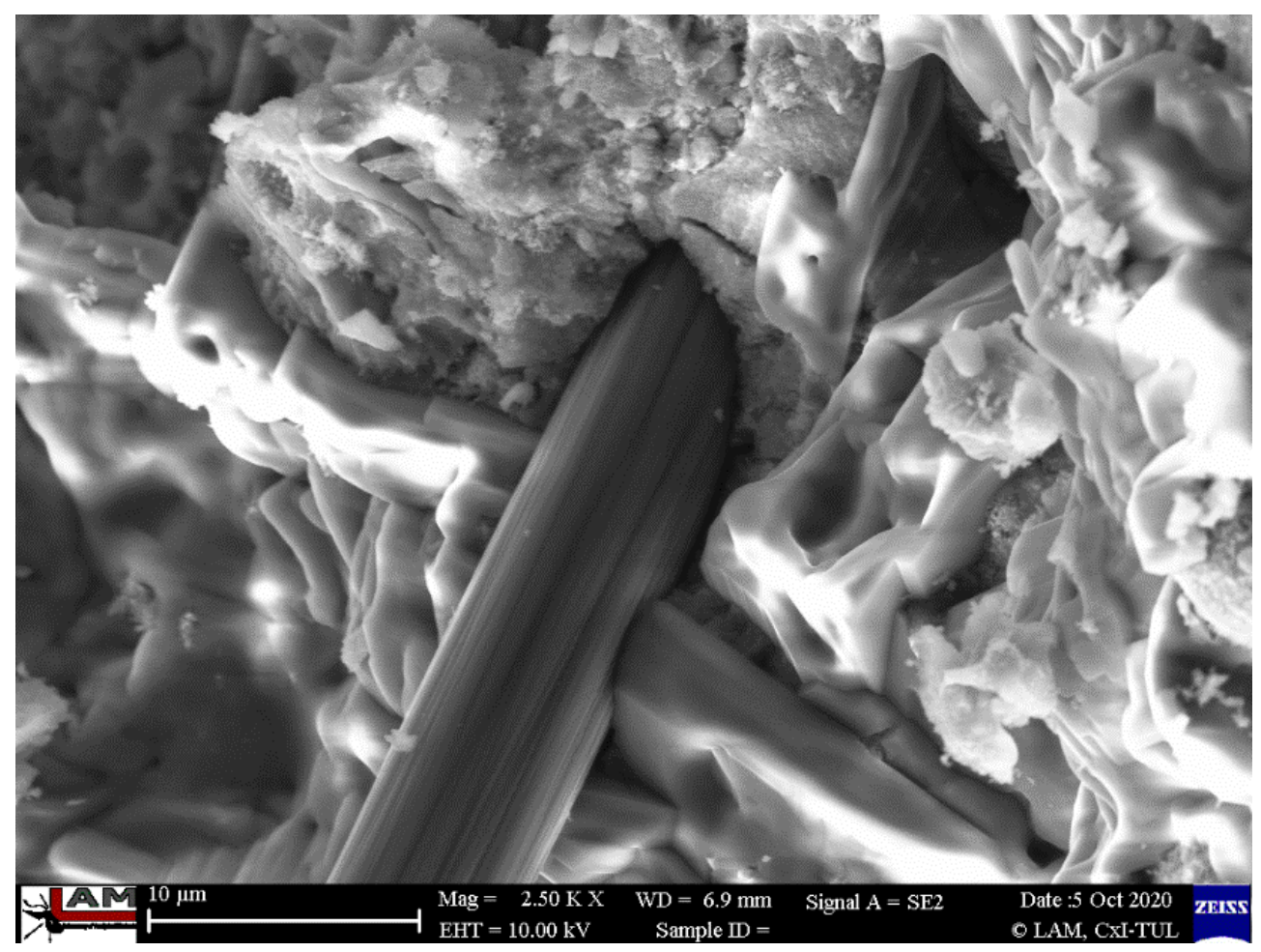

Figure 11. Microstructure of injected samples reinforced with a carbon fibers with visible lack of cohesion between the sample and the matrix. 


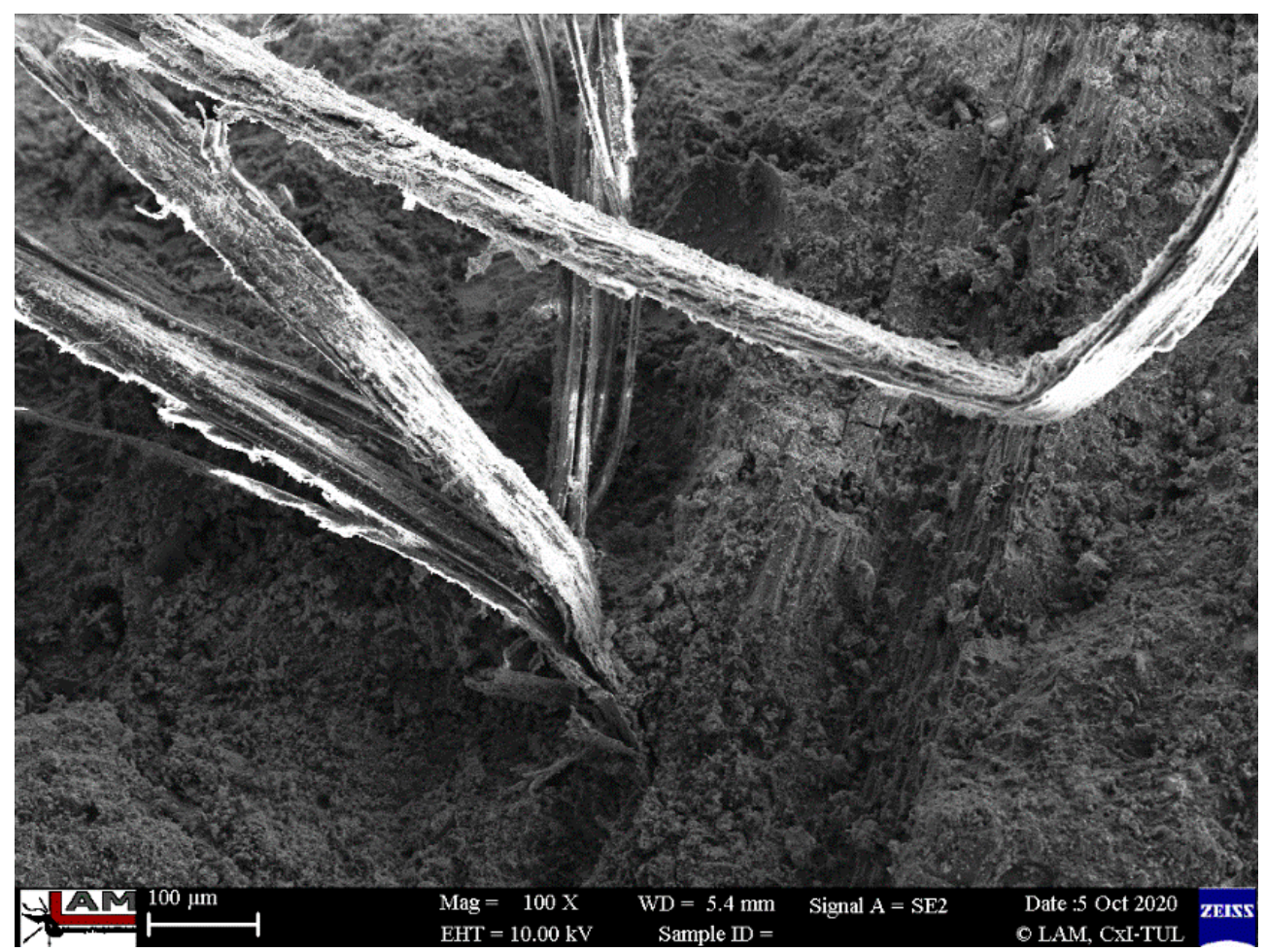

Figure 12. Microstructure of injected samples reinforced with flax fibers.

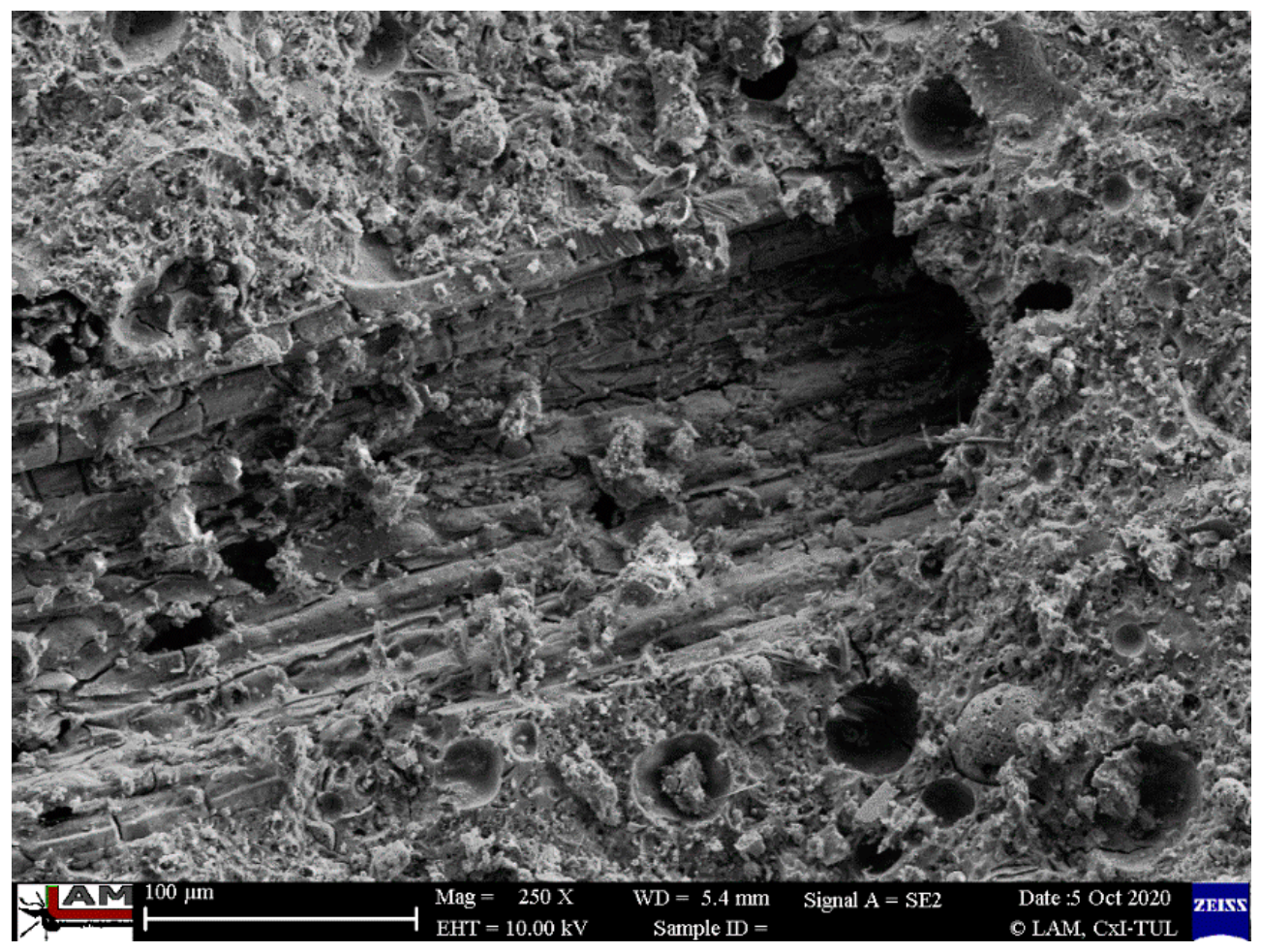

Figure 13. Microstructure of the cast samples reinforced with flax fibers with very good visible cohesion between the sample and the matrix. 


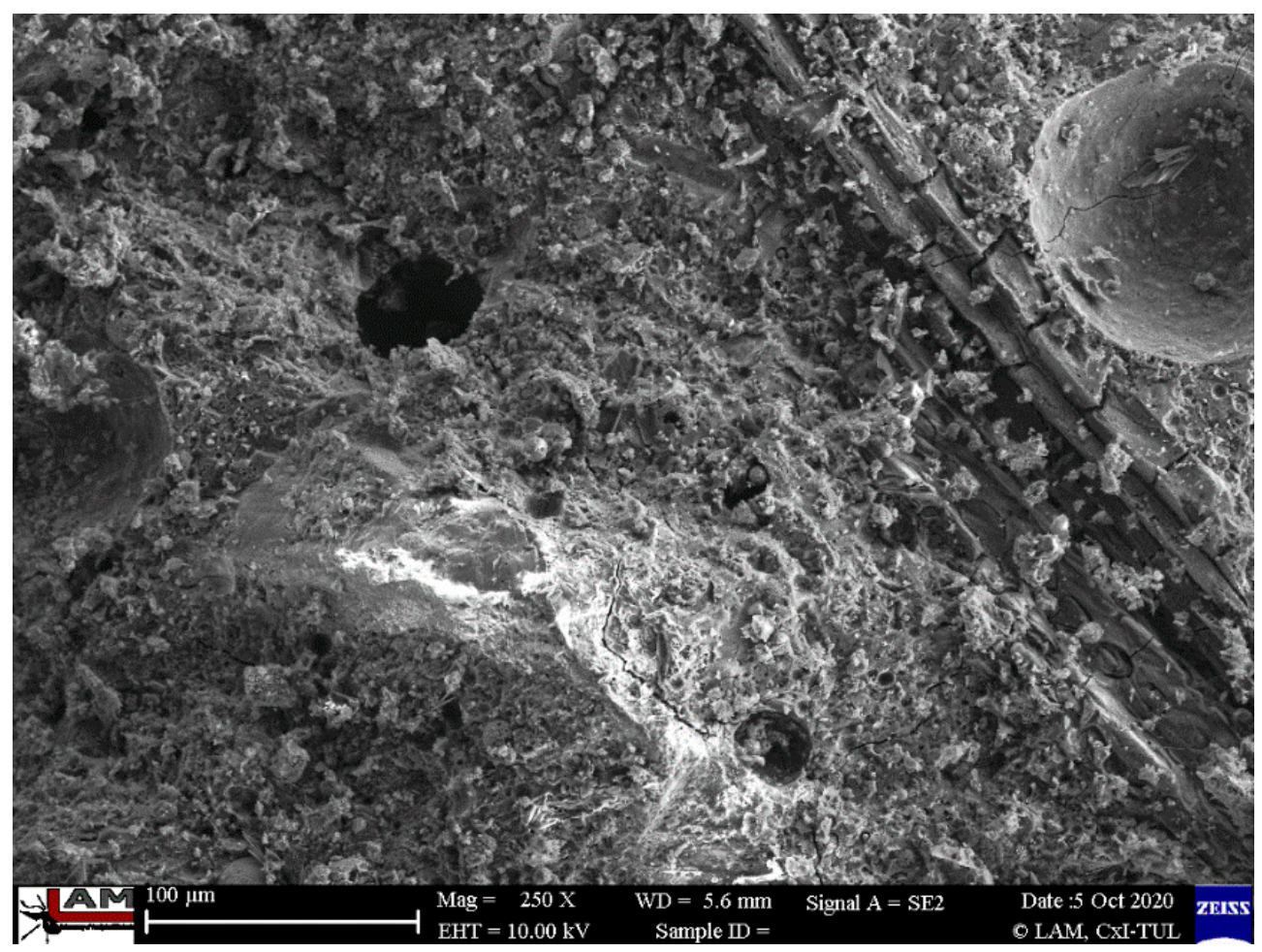

Figure 14. Microstructure of the cast samples reinforced with flax fibers with visible matrix structure and very good cohesion between sample and matrix.

In Figures 12-14, the microstructure of the material reinforced with flax fibers is presented. Natural reinforcement is generally reported to have worse mechanical properties than using artificial fibers such as carbon fiber $[2,17,70]$. Many publications reported the main cause to be the lack of coherence between the fiber and matrix [71,72]. The microstructural investigation does not confirm it in the case of provided research.

Figure 12 shows the structure of the flax fiber in the matrix. The structure is typical of natural fiber, irregular due to its different dimensions and rough surface [44,71].

Figure 13 presents the microstructure of the casted samples reinforced with flax fibers. The external part of the fibers is tightly joined to the matrix. During the mechanical tests, the fibers were broken, but they do not lose the coherence with the matrix.

In Figure 14, the microstructure of the injected samples reinforced with flax fibers is presented. There is no significant difference between the microstructure of the samples with the flax fibers that were injected (simulation of additive technology) and those that were casted. There is very good cohesion between fiber and the visible matrix.

The structure of the matrix is similar to that of the carbon fiber composites. Flax composites are characterized by better coherence between the fiber and the matrix. This partly explains the better mechanical properties of the samples with flax fiber. The microstructure observation does not explain the better results of compressive and flexural strength for the samples prepared by the additive technology method simulation (difference between production methods).

\section{Discussion}

Geopolymer composites based on fly ash reinforced with flax and carbon fibers were produced using two methods: casting, and simulation of additive manufacturing technology simulated by injection molding. In the first step, the mechanical properties were determined. The values obtained for the compressive strength were between 38.7 and $48.7 \mathrm{MPa}$. The obtained values for the flexural strength were between 8.1 and 9.4 MPa. Both of these results are in the range of values for fiber reinforced geopolymer composites $[2,3,72]$. The best values were achieved for the composite reinforced with $1 \%$ flax fiber 
made by simulation of the additive manufacturing method, and the worst values were achieved for the composite with $1 \%$ carbon fiber made by the same technology. There is a lack of visible tendency to change the mechanical properties of materials depending on the manufacturing method used. The samples reinforced by flax fibers have better mechanical properties than composites reinforced by carbon fiber. This result is not in line with previously published investigations that reported the predominantly better properties of synthetic fibers [1,73].

The investigation presented in the article attempts to explain the influence of material structure on the mechanical properties of the two kinds of geopolymer composites (flax and carbon reinforced) and the comparison of two methods of production for geopolymer composites (casting and 3D printing).

Analysis of bonding in the material by FT-IR shows similar bonds in all types of investigated composites. They consist mainly of free $\mathrm{O}-\mathrm{H}$, hydrogen-bonded $\mathrm{O}-\mathrm{H}, \mathrm{C}-\mathrm{O}$, Si-O-T and crystalline phase of quartz. FT-IR clearly shows the presence of aluminum silicates and/or aluminosilicates in geopolymers. FT-IR spectra are typical for geopolymer materials and show bonds typical for their internal structure [5].

The chemical and mineralogical composition (XRD and XRF) also do not show significant differences between the composites. The XRF investigation confirms the usefulness of the raw materials applied for the geopolymerization process. The high aluminum content and low calcium content promote the formation of 3D network in geopolymer materials. Additionally, the low amount of $\mathrm{CaO}$ supports the longer bonding process. Too high of a $\mathrm{CaO}$ content means that the binding process is too fast and therefore the geopolymerization process is not performed properly $[59,74]$. It has additional meaning in the case of additive manufacturing technology, where a hardening process that is too fast could have a negative influence on creating a proper interlayer bonding $[35,75]$.

Nuclear magnetic resonance spectroscopy shows that the composites have similar internal structures typical for geopolymer material. The data received are consistent with the findings of other research teams $[66,67]$. The 3D structure has been effectively created in the material.

The AFM investigation shows the difference between covering the fibers with the geopolymer matrix. It seems to confirm better coherence of the geopolymer made in additive technology with the reinforcement than that produced by the traditional casting method. However, it must be taken into consideration than this kind of test have a qualitative nature. The obtained results do not fully explain the differences in mechanical properties between the composites. There is a lack of comparative works in this area in the literature.

The microstructure was investigated by using confocal microscope as well as scanning electron microscope. The investigations provided by confocal microscopy revealed no significant differences between the samples produced by different methods. SEM observations confirm that the structure of the matrix is typical for fly ash-based geopolymers with aggregate [44] and there is a lack of differences between the matrixes in the four compositions. The investigations also show that the composites with flax fiber are characterized with better coherence between the fiber and matrix. It is extrusion technique.

The structure of the matrix is similar to that of carbon fibers. Flax composites are characterized with better coherence between the fiber and matrix. This partly explains the better mechanical properties of the samples with flax fiber. The microstructure observation does not explain the better results of compressive and flexural strength for the samples prepared by the additive technology simulation method (difference between production methods). This fact is not in line with previously published research, where artificial fibers usually have better coherence than natural ones $[2,17,70]$. The microscopy analysis does not satisfactorily explain the underlying reasons for the observed differences in the mechanical properties of the composites; in particular, it does not explain the better results of compressive and flexural strength for the samples prepared by simulation of additive technology method simulation (difference between production methods). 
The provided research does not show differences between casted samples and samples made by simulation of additive manufacturing technology. These research studies could show the potential for the development of additive manufacturing technology and the potential to replace it in many applications, including the building industry [76-78].

\section{Materials and Methods}

\subsection{Materials}

The raw materials for the geopolymer matrix were fly ash and sand ratio of 1:1. The sand was fine-grained saturated-surface dry construction sand (the surfaces of the sand particles are "dry" but the voids between the particles are saturated with water-there is no surface absorption) [14]. The fly ash came from the Skawina Combined Heat and Power Plant (Krakow, Lesser Poland region, Poland). It has a typical chemical composition for class $\mathrm{F}$, contains up to $5 \%$ unburned material, less than $10 \%$ iron compounds, and a low amount of calcium compounds $[44,54,79]$. Fly ash has good reactivity and workability: the reactive silica content is $36 \%$ and has $88 \%$ of the particles under the size of $45 \mu \mathrm{m}$; the specific density is $2.80 \mathrm{~g} / \mathrm{cm}^{3}[54,79]$.

Two types of fibers were used as reinforcement: green tow flax and carbon fibers [44]. They were added as $1 \%$ by mass of the composites. Green tow flax fibers are by-products of textile fiber production - they are coarse, broken fibers, removed during flax processing. After the process, they were dried. The fibers used for this study were shortened to around 5 $\mathrm{mm}$ in length. The fibers were delivered to the Faculty of Material Engineering and Physics, Cracow University of Technology by the Institute of Natural Fibers and Medicinal Plants (Poznan, Poland). Carbon fibers (P.P.H.U. SURFPOL Jacek Woźniak, Rawa Mazowiecka, Poland) have a length of $5 \mathrm{~mm}$ and a diameter of $8 \mu \mathrm{m}$ [44].

\subsection{Sample Preparation}

Firstly, the sodium promoter was prepared by mixing a 10-molar (10 M) sodium hydroxide solution $(\mathrm{NaOH})$ combined with a sodium water glass type R-145 solution (with molar module 2.5 and density about $1.45 \mathrm{~g} / \mathrm{cm}^{3}$ ). The proportion 1:2 was used. The alkaline solution was prepared by pouring an aqueous solution of sodium silicate into flakes of technical sodium hydroxide dissolved in tap water. The solution was left until the concentrations equalized and ambient temperature was reached (around $2 \mathrm{~h}$ ).

Next, the samples were prepared using sodium promoter, fly ash, sand and fibers $(1 \%$ by mass). The solid ingredients were added first, and then the liquid one. The components were mixed to receive the homogeneous paste. The mixing time was about $10 \mathrm{~min}$ on a low-speed mixing machine. Then, two methods of production were applied for the sample manufacturing:

(1) "CAST", in which traditional pouring molding was applied;

(2) " $3 \mathrm{D}$ ", in which the sample was made by injection molding to simulate the $3 \mathrm{D}$ printing process.

Finally, all samples (casted and injected) were heated in the laboratory drying cabinet for $24 \mathrm{~h}$ at $75{ }^{\circ} \mathrm{C}$. Afterwards, the samples were unmolded and stored in laboratory conditions (temperature ca. $20^{\circ} \mathrm{C}$, relative humidity ca. $50 \%$ ). The four series of samples were prepared (Table 6).

\subsection{Methods}

The compressive strength test was carried out in accordance with the EN 12390-3 procedure described in the standard for concrete EN 12390-3 ("Testing hardened concrete. The compressive strength of the test specimens") and the flexural strength test was carried out in accordance with the standard EN 12390-5 ("Testing hardened concrete and flexural strength of the test specimens"). Both tests were carried out on a Matest $3000 \mathrm{kN}$ universal strength testing machine (Matest, Treviolo, Italy) with a speed of $0.05 \mathrm{MPa} / \mathrm{s}$, calibration accuracy: class 1 . For each analyzed composition of geopolymer composites, a minimum of four samples were involved. The cubic samples (compressive strength) have the dimen- 
sions: $50 \mathrm{~mm} \times 50 \mathrm{~mm} \times 50 \mathrm{~mm}$, and the prismatic samples (flexural strength) have the dimensions: $50 \mathrm{~mm} \times 50 \mathrm{~mm} \times 200 \mathrm{~mm}$, with the distance between the support points equal to $150 \mathrm{~mm}$.

Table 6. Designation of manufactured composites.

\begin{tabular}{|c|c|c|c|c|c|c|}
\hline \multirow{2}{*}{ Designation } & \multicolumn{4}{|c|}{ Mixture Proportion (\% by Weight) } & \multirow{2}{*}{$\mathrm{NaOH}$ Solution } & \multirow{2}{*}{ Production Method } \\
\hline & Fly Ash & Sand & Carbon Fiber & Flax Fiber & & \\
\hline $3 \mathrm{DC}$ & 49.5 & 49.5 & 1.0 & - & \multirow{4}{*}{$\begin{array}{l}10 \mathrm{M} \text { sodium } \\
\text { hydroxide solution }+ \\
\text { water glass }(1200 \mathrm{~mL} \\
\text { in total })\end{array}$} & $\begin{array}{l}\text { injection molding to } \\
\text { simulate } 3 \mathrm{D} \text { printing }\end{array}$ \\
\hline CASTC & 49.5 & 49.5 & 1.0 & - & & $\begin{array}{l}\text { traditional molding } \\
\text { (casted) }\end{array}$ \\
\hline 3DF & 49.5 & 49.5 & - & 1.0 & & $\begin{array}{l}\text { injection molding to } \\
\text { simulate 3D printing }\end{array}$ \\
\hline CASTF & 49.5 & 49.5 & - & 1.0 & & $\begin{array}{l}\text { traditional molding } \\
\text { (casted) }\end{array}$ \\
\hline
\end{tabular}

Analysis of bonding in the material was carried out by the Department of Medical Physics of the Jagiellonian University with the use fourier-transform infrared spectroscopy (FT-IR) Spektromer FT-IR Nicolet 6700 (Nicolet, Klapálkova, Czech Republic).

The chemical and mineralogical composition were investigated by the Department of Silicates and Macromolecular Compounds, Faculty of Materials Science and Ceramics, AGH University of Science and Technology, with the use of spectroscopy (X-ray diffraction and X-ray fluorescence). X-ray fluorescence (XRF) was performed on Spektrometr WDXRF Axios mAX, equipped with Rh source Rh 4kW (PANalytical, Malvern, UK). XRD was analyzed using an $X^{\prime}$ Pert Pro MPD diffractometer (PANalytical) with $\mathrm{CuK} \alpha$ radiation at $30 \mathrm{~mA}$ and $40 \mathrm{kV}$. The $2 \theta$ angle varied between $20^{\circ}$ and $53^{\circ}$ with a step of $0.04^{\circ}$ and with an accumulation time of $7 \mathrm{~s}$ for each step.

Nuclear magnetic resonance spectroscopy (NMR) was provided by Department of Magnetic Resonance Tomography, The Henryk Niewodniczański Institute of Nuclear Physics Polish Academy of Sciences. There were made on pulsed magnetic resonance spectrometer (MS NMR), with the following parameters: APOLLO spectrometric console by Tecmag (two broadband channels for the $5-450 \mathrm{MHz}$ range, a digital receiver with a 14-bit ADC converter and a digital filter, a pulse recording programmer with a start of $100 \mathrm{~ns}$ ), AMT M3426 broadband high-frequency power amplifier (1 kW power in the range 30-120 MHz), Usoft PA300 high frequency narrowband power amplifier (1kW power at $300 \mathrm{MHz}$ ), MAGNEX superconducting magnet (7 T magnetic field, $89 \mathrm{~mm}$ gap, field homogeneity $0.2 \mathrm{ppm}$ for a $5 \mathrm{~mm}$ sphere), Bruker HP-WB 73A CP/MAS probe (two-channel, X channel: 44-122 MHz (2H-31P), 1H channel: $300 \mathrm{MHz}$, maximum spin frequency $15 \mathrm{kHz}$ ).

Research with the use of an atomic force microscope (AFM) was carried out by the Institute of Metallurgy and Materials Science of the Polish Academy of Sciences. The microscope ECSPM, Innova Bruker (Ettlingen, Germany), with NanoScope Analysis overview was provided. Bruker SPM Innova enables tests with tests up to $40 \mathrm{~mm}$ and thickness up to $18 \mathrm{~mm}$ in the range up to $100 \mu \mathrm{m}$ for $\mathrm{XY}$ and up to $7.5 \mu \mathrm{m}$ in $\mathrm{Z}$ in the contact and noncontact AFM modes. The apparatus also allows for atomic launch and allows for atomic thresholds in high-resolution mode. Image analysis software NanoScope Analysis aids correction and nonfogging results such as surface roughness, height of atomic thresholds, etc. NCHV measuring probes by Bruker on antimony-doped silicon with a sensor with the following characteristics were used: blade with radius $R=8 \mathrm{~nm}$, beam stiffness: $42 \mathrm{~N} / \mathrm{m}$ and resonance messages: approx. $330 \mathrm{kHz}$. The scanned area was selected each time for the possibilities for each sample. The method has a qualitative character.

The confocal microscopy investigations and scanning electron microscope (SEM) images were carried out in the Department of Material Science, Faculty of Mechanical Engineering, Technical University of Liberec. The SENSOFAR Metrology material confocal 
microscope working according to the ISO 25,178 standard was used for surface investigation on breakthroughs. Microstructure investigations with the use of the Carl Zeiss ULTRA Plus scanning electron microscope (SEM) type were also carried out on breakthroughs. The microscope has the following parameters: resolution: $1 \mathrm{~nm} @ 15 \mathrm{kV} ; 1.6 \mathrm{~nm} @ 1 \mathrm{kV}$, magnification: $12-1,000,000 \times$ in SE mode and acceleration voltage: $0.02-30 \mathrm{kV}$ ).

\section{Conclusions}

The investigation provided in the article focused on determining the influence of the microstructure of the material on the mechanical properties of the two kinds of geopolymer composites (flax and carbon reinforced) and the comparison of two methods of production for geopolymer composites (casting and 3D printing). By analyzing the results of the research presented in this paper, the following conclusions can be drawn:

(1) The best mechanical properties was reached for the sample made by simulating 3D printing process for the composite reinforced by flax fibers. It was $48.7 \mathrm{MPa}$ for the compressive strength and 9.4 MPa for flexural strength.

(2) FT-IR clearly shows the presence of aluminum silicates and/or aluminosilicates in geopolymers. The analysis shows that all investigated geopolymers composites have a similar internal structure, consisting of free $\mathrm{O}-\mathrm{H}$, hydrogen bonded $\mathrm{O}-\mathrm{H}, \mathrm{C}-\mathrm{O}$, $\mathrm{Si}-\mathrm{O}-\mathrm{Al}$ and $\mathrm{Si}-\mathrm{O}-\mathrm{Si}$ as well as the crystalline phase of quartz.

(3) The main elements of the composite structure showed by XRF are: oxygen (O), silica (Si), and aluminum (Al). The main oxides presented in the structure showed by XRF are: alumina- $\mathrm{Al}_{2} \mathrm{O}_{3}$ and silica-SiO $\mathrm{S}_{2}$. Moreover, the composite includes significant amounts of: $\mathrm{Fe}_{2} \mathrm{O}_{3}, \mathrm{Na}_{2} \mathrm{O}$ and $\mathrm{CaO}$. The obtained data are coherent with the applied raw materials, particularly they confirmed the applied fly ash has a composition relevant for the class $\mathrm{F}$. These elements come from raw materials used and are the basic element for creating the structure of the geopolymer and are similar for all investigated compositions.

(4) Identified phases showed by XRD are quartz, mullite, hematite, magnetite, anhydrite, albite, and sylimanite. A significant amount of quartz is associated with the use of sand as an aggregate. Among them, there are crystalline as well as amorphous phases. The mineralogical composition for all investigated materials is similar.

(5) NMR - The presented data show that all composites have a similar internal structure typical for geopolymer material. This investigation confirms, the presence of $\mathrm{SiO}_{4}$ and $\mathrm{AlO}_{4}$ tetrahedrons in a three-dimensional structure what is crucial for geopolymer structure.

(6) The AMF shows better coherence of the geopolymer made in additive technology to the reinforcement. The surface of the fibers is more evenly covered than in casted samples.

(7) The observations by confocal microscopy did not reveal significant differences between the samples produced by different methods. The fiber distribution is similar for all investigated compositions.

(8) The SEM observations show that the flax composites are characterized by better coherence between the fiber and the matrix. This partly explains the better mechanical properties of the samples with flax fiber. The microstructure observation does not explain the better results of compressive and flexural strength for the samples prepared by the additive technology method simulation (difference between production methods).

The results show the samples made by the additive technology had comparable properties with those made by casting method and similar structure. There is a lack of visible tendency to change the mechanical properties of materials depending on the manufacturing method used.

The application of additive technology in the construction industry could bring many advantages, such as low labor costs, less waste, and high efficiency. One of the main reasons for the limited use of this technology is the lack of material investigations. The materials still require development and optimization. One of the promising possibilities for further 
development is the reinforced geopolymer with fiber, which could be an eco-friendly alternative for concrete in many applications.

Author Contributions: Conceptualization, K.K.; methodology, K.K.; validation, K.K. and P.L.; formal analysis, K.K.; investigation, K.K. and P.K.; resources, K.K. and P.L.; writing-original draft preparation, K.K.; writing - review and editing, P.K. and P.L.; supervision, K.K.; project administration, K.K.; funding acquisition, K.K. All authors have read and agreed to the published version of the manuscript.

Funding: This research was funded by the Polish National Science Centre research project no. DEC2019/03/X/ST5/00618.

Institutional Review Board Statement: Not applicable.

Informed Consent Statement: Not applicable.

Data Availability Statement: Not applicable.

Acknowledgments: The authors thank Andrzej Wróbel from the Department of Medical Physics of the Jagiellonian University for help with providing FT-IR research and Piotr Ozga from the Institute of Metallurgy and Materials Science of the Polish Academy of Science for AMF analysis. The authors are grateful to Maciej Sitarz from Department of Silicates and Macromolecular Compounds, Faculty of Materials Science and Ceramics, AGH University of Science and Technology for help with XRF and XRD investigations. The authors appreciate the support of Wadysaw Wglarz from Department of Magnetic Resonance Tomography, The Henryk Niewodniczaski Institute of Nuclear Physics Polish Academy of Sciences, in NMR research.

Conflicts of Interest: The authors declare no conflict of interest. The funders had no role in the design of the study; in the collection, analyses, or interpretation of data; in the writing of the manuscript, or in the decision to publish the results.

\section{References}

1. Silva, G.; Kim, S.; Aguilar, R.; Nakamatsu, J. Natural fibers as reinforcement additives for geopolymers-A review of potential eco-friendly applications to the construction industry. Sustain. Mat. Technol. 2020, 23, e00132. [CrossRef]

2. Korniejenko, K.; Lin, W.T.; Šimonová, H. Mechanical Properties of Short Polymer Fiber-Reinforced Geopolymer Composites. J. Compos. Sci. 2020, 4, 128. [CrossRef]

3. Ma, C.K.; Awang, A.Z.; Omar, W. Structural and material performance of geopolymer concrete: A review. Constr. Build. Mater. 2018, 186, 90-102. [CrossRef]

4. Figiela, B.; Korniejenko, K. The Possibility of Using Waste Materials as Raw Materials for the Production of Geopolymers. Acta Innov. 2020, 36, 48-56. [CrossRef]

5. Shill, S.K.; Al-Deen, S.; Ashraf, M.; Hutchison, W. Resistance of fly ash based geopolymer mortar to both chemicals and high thermal cycles simultaneously. Constr. Build. Mater. 2020, 239, 117886. [CrossRef]

6. Pasupathy, K.; Berndt, M.; Sanjayan, J.; Rajeev, P.; Cheema, D.S. Durability performance of precast fly ash-based geopolymer concrete under atmospheric exposure conditions. J. Mater. Civ. Eng. 2018, 30, 04018007. [CrossRef]

7. Lahoti, M.; Tan, K.H.; Yang, E.H. A critical review of geopolymer properties for structural fire-resistance applications. Constr. Build. Mater. 2019, 221, 514-526. [CrossRef]

8. Bai, C.; Colombo, P. Processing, properties and applications of highly porous geopolymers: A review. Ceram. Int. 2018, 44, 16103-16118. [CrossRef]

9. Jiang, C.; Wang, A.; Bao, X.; Ni, T.; Ling, J. A review on geopolymer in potential coating application: Materials, preparation and basic properties. J. Build. Eng. 2020, 32, 101734. [CrossRef]

10. Wu, Y.; Lu, B.; Bai, T.; Wang, H.; Du, F.; Zhang, Y.; Cai, L.; Jiang, C.; Wang, W. Geopolymer, green alkali activated cementitious material: Synthesis, applications and challenges. Constr. Build. Mater. 2019, 224, 930-949. [CrossRef]

11. Amran, Y.H.M.; Alyousef, R.; Alabduljabbar, H.; El-Zeadani, M. Clean production and properties of geopolymer concrete; A review. J. Clean Prod. 2020, 251, 119679. [CrossRef]

12. Sandanayake, M.; Gunasekara, C.; Law, D.; Zhang, G.; Setunge, S.; Wanijuru, D. Sustainable criterion selection framework for green building materials-An optimisation based study of fly-ash Geopolymer concrete. Sustain. Mat. Technol. 2020, 25, e00178. [CrossRef]

13. Bumanis, G.; Vitola, L.; Pundiene, I.; Sinka, M.; Bajare, D. Gypsum, Geopolymers, and Starch-Alternative Binders for Bio-Based Building Materials: A Review and Life-Cycle Assessment. Sustainability 2020, 12, 5666. [CrossRef]

14. Bazan, P.; Kozub, B.; Łach, M.; Korniejenko, K. Evaluation of Hybrid Melamine and Steel Fiber Reinforced Geopolymers Composites. Materials 2020, 13, 5548. [CrossRef] 
15. Yao, Y.; Hu, M.; Di Maio, F.; Cucurachi, S. Life cycle assessment of 3D printing geo-polymer concrete. J. Ind. Ecol. 2019, 24, 116-127. [CrossRef]

16. Korniejenko, K.; Łach, M.; Chou, S.-Y.; Lin, W.-T.; Cheng, A.; Hebdowska-Krupa, M.; Gądek, S.; Mikuła, J. Mechanical Properties of Short Fiber-Reinforced Geopolymers Made by Casted and 3D Printing Methods: A Comparative Study. Materials 2020, 13, 579. [CrossRef]

17. Korniejenko, K.; Łach, M. Geopolymers reinforced by short and long fibres-innovative materials for additive manufacturing. Curr. Opin. Chem. Eng. 2020, 28, 167-172. [CrossRef]

18. Labonnote, N.; Rønnquist, A.; Manum, B.; Rüther, P. Additive construction: State-of-the-art, challenges and opportunities Automat. Constr. 2016, 72, 347-366. [CrossRef]

19. Panda, B.; Tan, M.J. Rheological behavior of high volume fly ash mixtures containing micro silica for digital construction application. Mater. Lett. 2019, 237, 348-351. [CrossRef]

20. Soltan, D.G.; Li, V.C. A self-reinforced cementitious composite for building-scale 3D printing. Cem. Concr. Comp. 2018, 90, 1-13. [CrossRef]

21. Ma, G.; Li, Z.; Wang, L. Printable properties of cementitious material containing copper tailings for extrusion based 3D printing. Constr. Build. Mater. 2018, 162, 613-627. [CrossRef]

22. Hager, I.; Golonka, A.; Putanowicz, R. 3D Printing of Buildings and Building Components as the Future of Sustainable Construction? Procedia Eng. 2016, 151, 292-299. [CrossRef]

23. Rahul, A.V.; Santhanam, M.; Meena, H.; Ghani, Z. 3D printable concrete: Mixture design and test methods. Cem. Concr. Comp. 2019, 97, 13-23. [CrossRef]

24. Panda, B.; Unluer, C.; Tan, M.J. Investigation of the rheology and strength of geopolymer mixtures for extrusion-based 3D printing. Cem. Concr. Comp. 2018, 94, 307-314. [CrossRef]

25. Xia, M.; Nematollahi, B.; Sanjayan, J. Printability, accuracy and strength of geopolymer made using powder-based 3D printing for construction applications. Automat. Constr. 2019, 101, 179-189. [CrossRef]

26. Xia, M.; Sanjayan, J.G. Methods of enhancing strength of geopolymer produced from powder-based 3D printing process. Mater. Lett. 2018, 227, 281-283. [CrossRef]

27. Zhang, D.W.; Wang, D.M.; Lin, X.Q.; Zhang, T. The study of the structure rebuilding and yield stress of 3D printing geopolymer pastes. Constr. Build. Mater. 2018, 184, 575-580. [CrossRef]

28. Ganesan, N.; Abraham, R.; Deepa Raj, S. Durability characteristics of steel fibre reinforced geopolymer concrete. Constr. Build. Mater. 2015, 93, 471-476. [CrossRef]

29. Srinivasan, K. Durability Studies on the Slag Based Geopolymer Concrete Strengthened with Steel Fibres. Int. J. Civ. Eng. Technol. 2017, 8, 239-250.

30. Ma, G.; Li, Z.; Wang, L.; Bai, G. Micro-cable reinforced geopolymer composite for extrusion-based 3D printing. Mater. Lett. 2019, 235, 144-147. [CrossRef]

31. Lim, J.H.; Panda, B.; Pham, Q.C. Improving flexural characteristics of 3D printed geopolymer composites with in-process steel cable reinforcement. Constr. Build. Mater. 2018, 178, 32-41. [CrossRef]

32. Li, Z.; Wang, L.; Ma, G. Mechanical improvement of continuous steel microcable reinforced geopolymer composites for 3D printing subjected to different loading conditions. Compos. Part B Eng. 2020, 187, 107796. [CrossRef]

33. Al-Qutaifi, S.; Nazari, A.; Bagheri, A. Mechanical properties of layered geopolymer structures applicable in concrete 3D-printing. Constr. Build. Mater. 2018, 176, 690-699. [CrossRef]

34. Panda, B.; Paul, S.C.; Tan, M.J. Anisotropic mechanical performance of 3D printed fiber reinforced sustainable construction material. Mater. Lett. 2017, 209, 146-149. [CrossRef]

35. Nematollahi, B.; Xia, M.; Sanjayan, J.; Vijay, P. Effect of Type of Fiber on Inter-Layer Bond and Flexural Strengths of Extrusion-Based 3D Printed Geopolymer. Mater. Sci. Forum 2018, 939, 155-162. [CrossRef]

36. Bong, S.H.; Nematollahi, B.; Xia, M.; Nazari, A.; Sanjayan, J.; Pan, J. Properties of 3D-printable ductile fibre-reinforced geopolymer composite for digital construction applications. In Rheology and Processing of Construction Materials; Mechtcherine, V., Khayat, K., Secrieru, E., Eds.; RILEM Bookseries; Springer: Cham, Switzerland, 2020; Volume 23, pp. 363-372.

37. Nematollahi, B.; Vijay, P.; Sanjayan, J.; Nazari, A.; Xia, M.; Nerella, V.N.; Mechtcherine, V. Effect of Polypropylene Fibre Addition on Properties of Geopolymers Made by 3D Printing for Digital Construction. Materials 2018, 11, 2352. [CrossRef]

38. Li, Z.; Wang, L.; Ma, G.; Sanjayan, J.; Feng, D. Strength and ductility enhancement of 3D printing structure reinforced by embedding continuous micro-cables. Constr. Build. Mater. 2020, 264, 120196. [CrossRef]

39. Muthukrishnan, S.; Ramakrishnan, S.; Sanjayan, J. Effect of microwave heating on interlayer bonding and buildability of geopolymer 3D concrete printing. Constr. Build. Mater. 2020, 265, 120786. [CrossRef]

40. Vlachakis, C.; Perry, M.; Biondi, L.; McAlorum, J. 3D printed temperature-sensing repairs for concrete structures. Addit. Manuf. 2020, 34, 101238. [CrossRef]

41. Archez, J.; Texier-Mandoki, N.; Bourbon, X.; Caron, J.F.; Rossignol, S. Shaping of geopolymer composites by 3D printing. J. Build. Eng. 2021, 34, 101894. [CrossRef]

42. Korniejenko, K.; Łach, M.; Chou, S.Y.; Lin, W.T.; Mikuła, J.; Mierzwiński, D.; Cheng, A.; Hebda, M. A comparative study of mechanical properties of fly ash-based geopolymer made by casted and 3D printing methods. IOP Conf. Ser. Mater. Sci. Eng. 2019, 660, 012005. [CrossRef] 
43. Panda, B.; Paul, S.C.; Hui, L.J.; Tay, Y.W.D.; Tan, M.J. Additive manufacturing of geopolymer for sustainable built environment. J. Clean. Prod. 2017, 167, 281-288. [CrossRef]

44. Korniejenko, K.; Miernik, K.; Lin, W.T.; Castel, A. The influence of microstructure on mechanical properties of 3D printable geopolymer composites. MATEC Web Conf. 2020, 322, 01011. [CrossRef]

45. Mucsi, G.; Molnár, Z.; Kumar, S. Geopolymerisation of Mechanically Activated Lignite and Brown Coal Fly Ash. Acta Phys. Pol. A 2014, 126, 994-998. [CrossRef]

46. Bakharev, T. Resistance of geopolymer materials to acid attack. Cem. Concr. Res. 2005, 35, 658-670. [CrossRef]

47. Bakharev, T. Durability of geopolymer materials in sodium and magnesium sulfate solutions. Cem. Concr. Res. 2005, 35, 1233-1246. [CrossRef]

48. Criado, M.; Palomo, A.; Fernández-Jiménez, A. Alkali activation of fly ashes. Part 1: Effect of curing conditions on the carbonation of the reaction products. Fuel 2005, 84, 2048-2054. [CrossRef]

49. Swanepoel, J.; Strydom, C. Utilisation of fly ash in a geopolymeric material. Appl. Geochem. 2002, 17, 1143-1148. [CrossRef]

50. Ismail, I.; Bernal, S.A.; Provis, J.L.; San Nicolas, R.; Hamdan, S.; van Deventer, J.S. Modification of phase evolution in alkaliactivated blast furnace slag by the incorporation of fly ash. Cem. Concr. Compos. 2014, 45, 125-135. [CrossRef]

51. Lee, W.; Van Deventer, J. Structural reorganisation of class F fly ash in alkaline silicate solutions. Colloids Surf. A. 2002, 211, 49-66. [CrossRef]

52. Mozgawa, W.; Król, M.; Dyczek, J.; Deja, J. Investigation of the coal fly ashes using IR spectroscopy. Spectrochim Acta A Mol. Biomol. Spectrosc. 2014, 132, 889-894. [CrossRef] [PubMed]

53. Liu, Y.; Zeng, F.; Sun, B.; Jia, P.; Graham, I.T. Structural Characterizations of Aluminosilicates in Two Types of Fly Ash Samples from Shanxi Province, North China. Minerals 2019, 9, 358. [CrossRef]

54. Korniejenko, K.; Halyag, N.P.; Mucsi, G. Fly Ash as a Raw Material for Geopolymerisation-Chemical Composition and Physical Properties. IOP Conf. Ser. Mater. Sci. Eng. 2019, 706, 012002. [CrossRef]

55. Bouaissi, A.; Li, L.Y.; Moga, L.M.; Sandu, I.G.; Al Bakri Abdullah, M.M.; Sandu, A.V.A. Review on Fly Ash as a Raw Cementitious Material for Geopolymer Concrete. Rev. Chim. Buchar. 2018, 69, 1661. [CrossRef]

56. Tennakoon, C.; Nazari, A.; Sanjayan, J.G.; Sagoe-Crentsil, K. Distribution of oxides in fly ash controls strength evolution of geopolymers. Constr. Build. Mater. 2014, 71, 72-82. [CrossRef]

57. Singh, N.B. Fly Ash-Based Geopolymer Binder: A Future Construction Material. Minerals 2018, 8, 299. [CrossRef]

58. Singh, N.B.; Saxena, S.K.; Kumar, M.; Rai, S. Geopolymer cement: Synthesis, Characterization, Properties and applications. Mater. Today Proc. 2019, 15, 364-370. [CrossRef]

59. Yang, T.; Han, E.; Wang, X.; Wu, D. Surface decoration of polyimide fiber with carbon nanotubes and its application for mechanical enhancement of phosphoric acid-based geopolymers. Appl. Surf. Sci. 2017, 416, 200-212. [CrossRef]

60. Part, W.K.; Ramli, M.; Cheah, C.B. An overview on the influence of various factors on the properties of geopolymer concrete derived from industrial by-products. Constr. Build. Mater. 2015, 77, 370-395. [CrossRef]

61. Rickard, W.D.A.; Riessen, A.; Walls, P. Thermal character of geopolymers synthesized from class F fly ash containing high concentrations of iron and $\alpha$-quartz. Int. J. Appl. Ceram. Technol. 2010, 7, 81-88. [CrossRef]

62. Nikolić, V.; Komljenović, M.; Baščarević, Z.; Marjanović, N.; Miladinović, Z.; Petrović, R. The influence of fly ash characteristics and reaction conditions on strength and structure of geopolymers. Constr. Build. Mater. 2015, 94, 361-370. [CrossRef]

63. Kumar, S.; Mucsi, G.; Kristály, F.; Pekker, P. Mechanical activation of fly ash and its influence on micro and nano-structural behaviour of resulting geopolymers. Adv. Powder Technol. 2017, 28, 805-813. [CrossRef]

64. Davidovits, J. Geopolymer Chemistry and Applications, 4th ed.; Geopolymer Institute: Saint-Quentin, France, $2015 ;$ p. 644.

65. Provis, J.L.; Van Deventer, J.S.J. Alkali Activated Materials. RILEM State-of-the-Art Reports; Springer: Dordrecht, The Netherlands, 2014.

66. Davidovits, J. Properties of geopolymer cements. In Proceedings of the First International Conference on Alkaline Cements and Concretes, Kiev, Ukraine, 11-14 October 1994; Kiev State Technical University Scientific Research Institute on Binders and Materials: Kiev, Ukraine, 1994; pp. 131-149.

67. Singh, P.S.; Bastow, T.; Trigg, M. Structural Studies of Geopolymers by 29Si and 27Al MAS-NMR. J. Mater. Sci. 2005, 40, 3951-3961. [CrossRef]

68. Ranjbar, N.; Zhang, M. Fiber-reinforced geopolymer composites: A review. Cem. Concr. Comp. 2020, 107, 103498. [CrossRef]

69. Adesina, A. Performance of fibre reinforced alkali-activated composites-A review. Materialia 2020, 12, 100782. [CrossRef]

70. Silva, G.; Kim, S.; Bertolotti, B.; Nakamatsu, J.; Aguilar, R. Optimization of a reinforced geopolymer composite using natural fibers and construction wastes. Constr. Build. Mater. 2020, 258, 119697. [CrossRef]

71. Korniejenko, K.; Łach, M.; Hebdowska-Krupa, M.; Mikuła, J. The mechanical properties of flax and hemp fibres reinforced geopolymer composites. IOP Conf. Ser. Mater. Sci. Eng. 2018, 379, 012023. [CrossRef]

72. Al-Mashhadani, M.M.; Canpolat, O.; Aygörmez, Y.; Uysal, M.; Erdem, S. Mechanical and microstructural characterization of fiber reinforced fly ash based geopolymer composites. Constr. Build. Mater. 2018, 167, 505-513. [CrossRef]

73. Rashad, A.M. Effect of steel fibers on geopolymer properties-The best synopsis for civil engineer. Constr. Build. Mater. 2020, 246, 118534. [CrossRef]

74. Dombrowski, K.; Buchwald, A.; Weil, M. The Influence of Calcium Content on the Structure and Thermal Performance of Fly Ash Based Geopolymers. J. Mater. Sci. 2007, 42, 3033. [CrossRef] 
75. Panda, B.; Unluer, C.; Tan, M.J. Extrusion and rheology characterization of geopolymer nanocomposites used in 3D printing. Compos. Part B Eng. 2019, 176, 107290. [CrossRef]

76. Xia, M.; Sanjayan, J. Method of formulating geopolymer for 3D printing for construction applications. Mater. Des. 2016, 110, 382-390. [CrossRef]

77. Silva, G.; Quispe, L.; Kim, S.; Nakamatsu, J.; Aguilar, R. Development of a stabilized natural fiber-reinforced earth composite for construction applications using 3D printing. IOP Conf. Ser. Mater. Sci. Eng. 2019, 706, 012015. [CrossRef]

78. Bong, S.H.; Nematollahi, B.; Nazari, A.; Xia, M.; Sanjayan, J. Method of Optimisation for Ambient Temperature Cured Sustainable Geopolymers for 3D Printing Construction Applications. Materials 2019, 12, 902. [CrossRef]

79. Korniejenko, K.; Łach, M.; Marczyk, J.; Ziejewska, C.; Halyag, N.P.; Mucsi, G. Fly Ash as a Raw Material for GeopolymerisationMineralogical Composition and Morphology. IOP Conf. Ser. Mater. Sci. Eng. 2019, 706, 012006. [CrossRef] 